\title{
Poly(ADP-Ribose) Polymerases in Plants and Their Human Counterparts: Parallels and Peculiarities
}

\author{
Dagmar Rissel $1,2,3, *$ and Edgar Peiter $1,2, *$ (i) \\ 1 Plant Nutrition Laboratory, Institute of Agricultural and Nutritional Sciences, Faculty of Natural Sciences III, \\ Martin Luther University Halle-Wittenberg, 06099 Halle (Saale), Germany \\ 2 Agrochemisches Institut Piesteritz e.V. (AIP), Möllensdorfer Strasse 13, \\ 06886 Lutherstadt Wittenberg, Germany \\ 3 Institute for Plant Protection in Field Crops and Grassland, Julius Kühn-Institut (JKI), \\ 38104 Braunschweig, Germany \\ * Correspondence: dagmar.rissel@julius-kuehn.de (D.R.); edgar.peiter@landw.uni-halle.de (E.P.)
}

Received: 21 February 2019; Accepted: 29 March 2019; Published: 2 April 2019

check for updates

\begin{abstract}
Poly(ADP-ribosyl)ation is a rapid and transient post-translational protein modification that was described first in mammalian cells. Activated by the sensing of DNA strand breaks, poly(ADP-ribose)polymerase1 (PARP1) transfers ADP-ribose units onto itself and other target proteins using $\mathrm{NAD}^{+}$as a substrate. Subsequently, DNA damage responses and other cellular responses are initiated. In plants, poly(ADP-ribose) polymerases (PARPs) have also been implicated in responses to DNA damage. The Arabidopsis genome contains three canonical PARP genes, the nomenclature of which has been uncoordinated in the past. Albeit assumptions concerning the function and roles of PARP proteins in planta have often been inferred from homology and structural conservation between plant PARPs and their mammalian counterparts, plant-specific roles have become apparent. In particular, PARPs have been linked to stress responses of plants. A negative role under abiotic stress has been inferred from studies in which a genetic or, more commonly, pharmacological inhibition of PARP activity improved the performance of stressed plants; in response to pathogen-associated molecular patterns, a positive role has been suggested. However, reports have been inconsistent, and the effects of PARP inhibitors appear to be more robust than the genetic abolition of PARP gene expression, indicating the presence of alternative targets of those drugs. Collectively, recent evidence suggests a conditionality of stress-related phenotypes of parp mutants and calls for a reconsideration of PARP inhibitor studies on plants. This review critically summarizes our current understanding of poly(ADP-ribosylation) and PARP proteins in plants, highlighting similarities and differences to human PARPs, areas of controversy, and requirements for future studies.
\end{abstract}

Keywords: abiotic stress; Arabidopsis thaliana; PAMP; PARP; poly(ADP-ribose) polymerase; poly(ADP-ribosyl)ation; SRO protein

\section{Introduction}

Poly(ADP-ribosyl)ation describes the rapid and transient posttranslational transfer of negatively charged ADP-ribose molecules onto proteins. First, ADP-ribose moieties are covalently attached to the target proteins. Subsequently, poly(ADP-ribose) chains of various length and branching complexity are synthesized, forming O-glycosidic bonds between the ADP-ribose molecules [1-5] (Figure 1). The enzymes catalyzing poly(ADP-ribosyl)ation are named poly(ADP-ribose) polymerases (PARPs). NAD ${ }^{+}$serves as substrate for poly(ADP-ribose) synthesis, and nicotinamide is formed as a concomitant product $[3,6,7]$. The synthesized ADP-ribose polymers constitute an interaction platform 
to modulate cellular responses. In animals, several poly(ADP-ribosyl)ation site-containing proteins and poly(ADP-ribose) binding motif-containing proteins have been identified acting as poly(ADP-ribose) readers translating the poly(ADP-ribose) signal into cellular responses [8,9]. These proteins are components of essential cellular processes such as DNA repair, cell cycle checkpoints, chromatin remodeling, signaling, protein degradation, and cell death [10-25]. The amino acids modified by poly(ADP-ribosyl)ation in the target proteins are predominantly glutamic acid and aspartic acid; modification is performed via ester linkage [26-28]. Recently, the modification of serine residues of target proteins by O-glycosidic bonds has been shown [29]; the enzymatic modification of lysine residues is currently a matter of debate $[27,28]$.

In contrast to their mammalian counterparts, less is known about the functions of plant poly(ADP-ribose)polymerases. In this review, we will first briefly highlight the current understanding of the function and roles of PARP proteins in humans and subsequently elaborate the similarities and differences in structure and function of their plant homologs. We will focus on plant-specific roles, such as in seeds, and in the determination of stress resistance by those proteins, which is currently a matter of controversy.

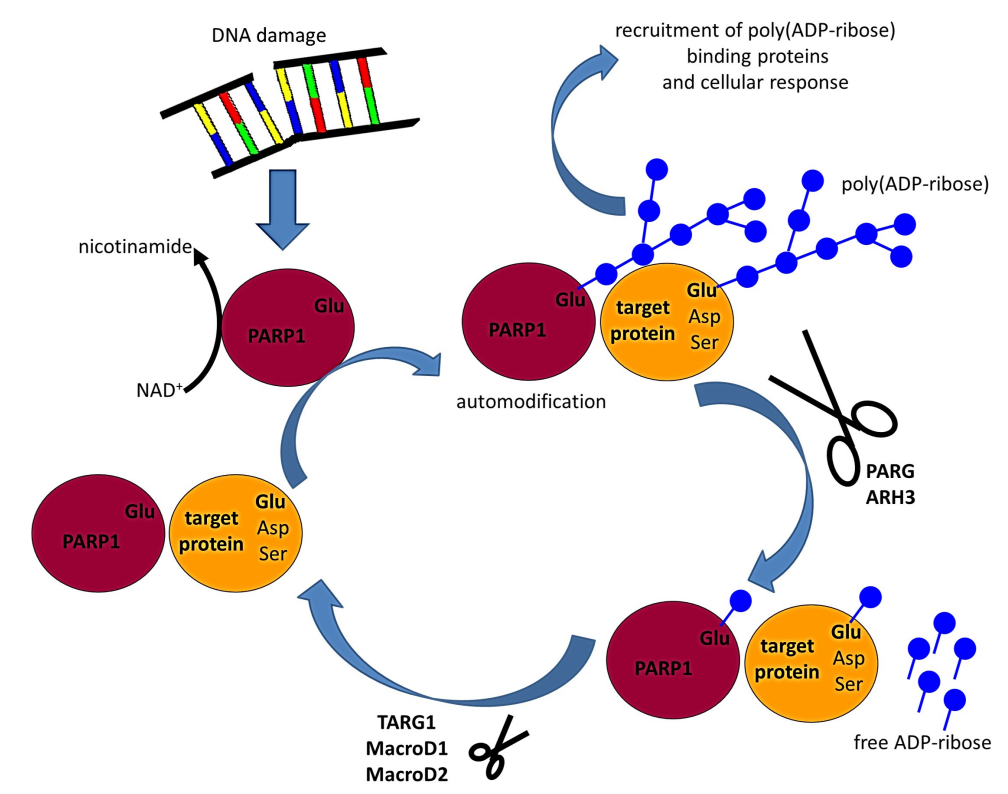

Figure 1. Cellular 'life cycle' of ADP-ribose polymers as inferred from studies on the human proteins. Activated upon DNA strand break, poly(ADP-ribose) polymerase1 (PARP1) and PARP2 catalyze the transfer of ADP-ribose molecules onto itself and other target proteins. The generated ADP-ribose polymers serve as scaffolds recruiting proteins containing various poly(ADP-ribose)-binding domains, which initiates cellular responses. The ribose-ribose bonds are hydrolyzed by Poly(ADP-ribose) glycohydrolase (PARG), ADP-ribose hydrolase 3 (ARH3), Terminal ADP-ribose glycohydrolase 1 (TARG1), MacroD1, and MacroD2, allowing rapid poly(ADP-ribose) turnover and controlled cellular signaling processes.

\section{Poly(ADP-Ribosyl)ation and Poly(ADP-Ribose) Polymerases (PARPs) in Humans}

\subsection{PARPs Constitute a Heterogeneous Protein Family in Humans}

PARP proteins have been found in all kingdoms of life except yeast [30,31]. In the human genome, 17 PARP genes have been identified [5,32-34]. They constitute a heterogeneous protein family with distinct structural domains, subcellular localizations, activities, and functions [32]. According to their structures and functions, the different PARP proteins were classified as DNA-dependent PARPs (PARP1, PARP2, PARP3) which are activated upon DNA damage; Tankyrases (PARP5a, PARP5b) which are involved in telomere homeostasis, DNA repair, mitotic spindle formation, and cellular signaling; 
Cys-Cys-Cys-His zinc finger and WWE poly(ADP-ribose)-binding domain-containing PARPs (PARP7, PARP12, PARP13.1, PARP13.2); and poly(ADP-ribose)-binding macrodomain-containing PARPs (PARP9, PARP14, PARP15) $[8,27,32,35]$. The last two groups are defined according to their protein structure, and, so far, little is known about the function of their members. The remaining PARP proteins are grouped as unclassified PARPs, as their domain architecture differs from each other and from the other groups [35]. To catalyze poly(ADP-ribosyl)ation, the catalytic triad motif H-Y-E within the catalytic PARP domain is essential but not sufficient $[36,37]$. Therefore, only PARP1, PARP2, and the Tankyrases are bona fide PARPs. PARP3, PARP4, PARP6, PARP10, PARP14, PARP15, and PARP16 were found to exhibit mono(ADP-ribosyl)ation activity catalyzing the addition of a single ADP-ribose molecule onto target proteins. No catalytic activity has been found for PARP9 and PARP13 [37].

\subsection{PARP1, PARP2, and PARP3 Are Activated upon DNA Damage}

The best-studied PARP protein is the founding member of the protein family, PARP1 [5]. It is the most abundant PARP enzyme in mammalian cells and accounts for approximately $85 \%$ of poly(ADP-ribosyl)ation activity [32]. Human PARP1 is a $113 \mathrm{kDa}$ protein with a well-defined modular architecture (Figure 2) [32]. It possesses an N-terminal DNA interaction domain, a central automodification domain, and a C-terminal catalytic domain [9,32,38]. This catalytic region is highly conserved in mammals, particularly the 50 amino acid-spanning so-called "PARP signature" [38]. The PARP signature forms the active site of the PARP proteins and exhibits 100\% conservation among vertebrates and $92 \%$ among all species [38]. Additionally, a WGR domain, named after its repeating amino acid motif (W-G-R), is located in the catalytic region. Apart from the glutamate moieties that allow automodification of PARP1, the central automodification domain contains a BRCT (breast cancer susceptibility gene $1 \mathrm{C}$-terminus) domain that is known to be involved in protein-protein interactions [39]. This domain is commonly found in DNA damage response proteins [39]. Three zinc fingers, a bipartite nuclear localization signal, and a caspase (cysteine proteases cleaving at an aspartic acid) cleavage site form the DNA-binding domain. The two homologous zinc fingers Zn1 and $\mathrm{Zn} 2$ are able to bind to DNA single and double strand breaks and abnormal DNA structures [40-42]. The third zinc finger, $\mathrm{Zn} 3$, is structurally unique and required for the activation of DNA-dependent catalytic activity of PARP1 [43]. Upon association with damaged DNA, the Zn3 and WGR domains refold to allow enhanced interdomain contacts and facilitate PARP1 catalytic activity [42]. Additional conformational changes within PARP1 lead to further activation $[8,44-46]$.

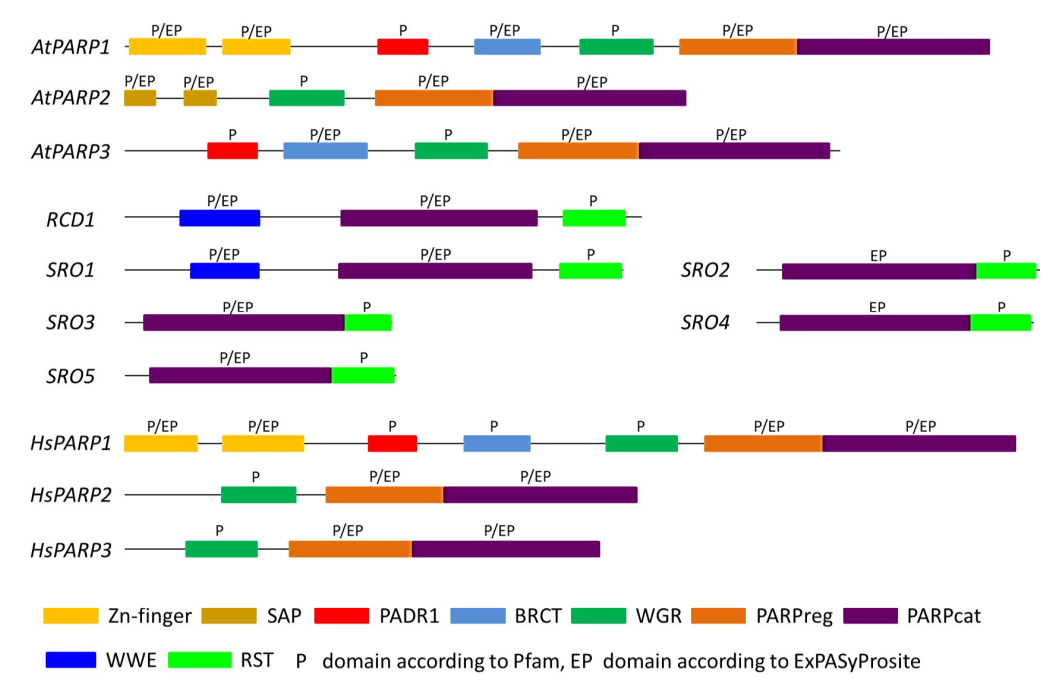

Figure 2. Schematic representation of domains in PARP proteins from humans and Arabidopsis thaliana. Domains were defined according to Pfam 27.0 and are displayed as colored boxes. ExPASY Prosite indicated the existence of PARPcat domains also in SRO2 and SRO4 which are absent in the Pfam analysis. Figure taken from [47]. 
Upon activation, PARP1 automodification and poly(ADP-ribosyl)ation of target proteins take place, recruiting DNA damage response proteins to the lesions (Figure 1). The negative charges of automodified PARP1 proteins repulse proteins from the DNA to allow access for the DNA damage repair machinery [9]. PARP1 has been found to be involved in virtually all DNA damage response pathways. Upon sensing DNA single strand breaks, PARP1 automodification recruits XRCC1 which scaffolds the assembly and activation of the base excision repair machinery and the subsequent repair of the small lesions caused by oxidation or alkylation [3,48-50]. Additionally, PARP1 was implied to be involved in homologous recombination (HR) repair of DNA double strand breaks (DSB), since components of the HR machinery such as MRE11 (mitotic recombination 11) and ATM (ataxia telangiectasia-mutated) are rapidly recruited to DNA damage sites in a poly(ADP-ribose)-dependent manner $[13,14,51]$. In line with this, PARP1 acts as a facilitator of HR repair at stalled DNA replication forks, as PARP1 binding to the stalled fork prevents the assembly of the non-homologous end joining (NHEJ) complex $[9,52,53]$. Contrastingly, PARP1 was also shown to interact with Ku70/Ku80 proteins, which are known key players in NHEJ $[53,54]$. However, its precise role in NHEJ is intricate, as classical NHEJ still proceeds in the absence of PARP1 [53]. As PARP1 competes with Ku proteins for DNA binding, it appears not to be a core component of classical NHEJ but of an alternative NHEJ pathway [55]. In line with its function in DNA damage responses, PARP1 also acts in chromosome remodeling, establishment and maintenance of heterochromatin, and transcriptional regulation $[4,8,25,56]$. In addition, PARP1 has also been implicated in various processes of cell death, such as apoptosis, parthanatos, programmed necrosis, and autophagy [24]. The common denominator of all these processes is an excessive formation of poly(ADP-ribose). During apoptosis, the increased PARP1 activity depletes the cellular energy pool, leading to an activation of caspases. The caspase-mediated cleavage of PARP1 is a hallmark of apoptosis, leading to the accomplishment of apoptotic cell death. Upon excessive activation of PARP1, poly(ADP-ribose) molecules appear to leave the nucleus and invade the mitochondria. Here, poly(ADP-ribose) is bound by AIF (apoptosis-inducing factor), which in turn is translocated to the nucleus where it promotes DNA fragmentation leading to parthanatos. During programmed necrosis and autophagy, PARP1 interacts with key components of both pathways, hence promoting cell death [24].

PARP2 was identified in a study initiated to resolve the source of residual poly(ADP-ribose) formation in cells lacking PARP1 [57]. It accounts for approximately $15 \%$ of overall cellular poly(ADP-ribose) synthesis [32]. The domain architecture of PARP2 differs from that of PARP1 (Figure 2). PARP2 consists of an N-terminal region (NTR) containing a nuclear and a nucleolar localization signal and a caspase cleavage site, a WGR domain, and a catalytic PARP domain [57-59]. The NTR lacks the zinc finger domain found in PARP1 and is an intrinsically disordered protein region allowing flexible adaptation to various damaged DNA structures such as gaps, flaps, and recombination intermediates [59]. However, the NTR does not localize to DNA damage sites on its own. The WGR and the catalytic domain are necessary and sufficient to direct PARP2 to DNA damage sites. The WGR domain is also involved in the activation of poly(ADP-ribosyl)ation by PARP2 [59]. The catalytic domains of PARP1 and PARP2 exhibit $69 \%$ homology [57]. Additionally, the catalytic domain was found to contribute to the binding affinity and the localization to the DNA damage sites [59]. Even though PARP2 lacks a conserved automodification domain, it is capable of automodification [58]. PARP1 and PARP2 were found to form heterodimers and poly(ADP-ribosyl)ate each other [60]. Additionally, PARP2 has been shown to interact with an overlapping, but distinct, set of proteins compared to PARP1 [61]. In line with this, PARP2 was found to be an actor in the response to DNA single strand break, similar to PARP1 [60,62]. Moreover, redundancy between PARP1 and PARP2 has been shown in cell survival and at stalled replication forks $[63,64]$. PARP2 has also been found to be involved in the choice of DSB repair modes, channeling repair towards HR or an alternative NHEJ [65]. The exact roles of PARP1 and PARP2 in DNA DSB response still have to be further elucidated. 
To date, less information is available on PARP3. Similar to PARP1 and PARP2, it is activated by DNA strand breaks [4] and it confers mono(ADP-ribosyl)ation activity [32] and functions in DNA DSB repair $[66,67]$. Thereby, PARP3 is efficiently recruited to DNA damage sites and interacts with proteins of the classical NHEJ pathway $[66,68]$. Additionally, PARP3 prevents DNA end resection, and as a consequence promotes classical NHEJ [53]. Apart from this, PARP3 mono(ADP-ribosyl)ates PARP1, kick-starting its activation [69].

\subsection{The Removal of Poly(ADP-Ribose) Is a Two-Step Process}

So far, five enzymes have been identified to degrade poly(ADP-ribose) chains, allowing rapid and dynamic poly(ADP-ribose) turnover (Figure 1) [8,9]. The key enzyme among them is poly(ADP-ribose)glycohydrolase (PARG) $[30,70,71]$. PARG possesses exoglycosidic and endoglycosidic activity, hydrolyzing terminal and internal ribose-ribose linkages, respectively, hence releasing ADP-ribose oligomers [71-73]. PARG enzymes, however, are not capable of cleaving the ester bond between the ADP-ribose molecule and the acceptor amino acids of the target protein. To date, only one PARG gene has been identified in mammals, but five protein isoforms resulting from alternative splicing have been found in different cellular compartments [74,75]. PARG protein function is essential, as genetic deletions of PARG in mice or Drosophila are lethal $[76,77]$. Similar to PARG, ADP-ribosyl-hydrolase 3 (ARH3) was found to exhibit poly(ADP-ribose)-hydrolyzing activity in the nucleus, the cytosol and the mitochondrion (Figure 1) [78,79]. ARH3 shares only little structural similarity with PARG; it accounts for $10 \%$ of the poly(ADP-ribose)-hydrolyzing activity in the cell $[78,79]$. The macrodomain-containing proteins Terminal ADP-Ribose protein Glycohydrolase 1 (TARG1) and Macrodomain-containing protein D1 (MacroD1) and MacroD2 possess the ability to hydrolyze the ester bond between the ribose and the acceptor amino acid (Figure 1) [80-82].

\section{Poly(ADP-Ribosyl)ation in Plants}

\subsection{Three Canonical PARP Proteins Have Been Identified in the Model Plant Arabidopsis thaliana}

In the late 1970s, poly(ADP-ribosyl)ation activity was shown in higher plants by the incorporation of $\left[{ }^{3} \mathrm{H}\right] \mathrm{NAD}$ into nuclei of onion and wheat embryo cells and onion meristematic root tissues [83-86]. This incorporation was found to be an enzymatic reaction covalently linking poly(ADP-ribose) molecules to carboxyl groups of the target proteins [87]. Lysine-rich histones H1, H2A and H2B, but not arginine-rich histones $\mathrm{H} 3$ and $\mathrm{H} 4$ were identified as acceptor proteins for poly(ADP-ribose) molecules [86,87]. In addition, automodification of a 114 to $116 \mathrm{kDa}$ protein was described in these early times of poly(ADP-ribose) research in plants $[87,88]$.

The first PARP gene identified in plants was Arabidopsis thaliana APP (At4g02390) [89]. In this review, APP will be called AtPARP2 as it is structurally most similar to human PARP2 (Figure 2; Table 1). The AtPARP2 cDNA was identified due to its $62 \%$ similarity to the catalytic domain of human PARP1 during experiments carried out to identify Arabidopsis proteins that allow yeast cells to grow under stress conditions. The AtPARP2 protein consists of 637 amino acids and has a size of $72 \mathrm{kDa}$. The PARP signature is conserved in AtPARP2. Apart from that, a nuclear localization signal and an automodification domain were found. In contrast to human PARP1, which possesses N-terminal zinc-finger domains, AtPARP2 contains an N-terminal SAP domain (Figure 2). The SAP domain is a putative DNA-binding domain involved in nucleic acid metabolism, named after three proteins that contain it (SAF-A/B, Acinus and PIAS) [90]. Expression of AtPARP2 in yeast revealed a nuclear localization and poly(ADP-ribosyl)ating activity. The main polymer size was 10 to 15 residues, but polymers of up to 40 ADP-ribosyl residues were formed [91]. The poly(ADP-ribosyl)ating activity was reduced by PARP inhibitors, 3-aminobenzamide (3AB) and nicotinamide. Nuclear localization of AtPARP2 in planta has been confirmed by transient expression of AtPARP2-GFP constructs in Nicotiana benthamiana and Arabidopsis [92-94]. It has recently been shown that nuclear import of AtPARP2 is mediated by Importin- $\alpha$ [94]. In addition to its nuclear localization, AtPARP2 has been 
suggested to be partially localized in chloroplasts [93]. Promoter-GUS fusions and RNA in situ hybridization studies showed AtPARP2 expression in imbibed seeds, the vegetative meristem of the shoot apex, stamen of open flowers, and late stages of embryo development [93].

AtPARP1 (At2g31320) was identified in a screen for ionizing radiation-induced genes in Arabidopsis thaliana [95]. AtPARP1 consists of 983 amino acids and exhibits conserved structural motifs compared to human PARP1. Similar to human PARP1, AtPARP1 contains a conserved catalytic domain, zinc finger motifs, and a nuclear localization motif (Figure 2). The central automodification domain is less conserved, but glutamate residues are present, allowing auto poly(ADP-ribosyl)ation. Apart from this, the BRCT domain, allowing protein-protein interactions, is also less conserved. Generally, the structural similarities between AtPARP1 and human PARP1 indicate functional similarities. This assumption was recently further supported by a yeast expression study, in which AtPARP1 expression inhibited yeast cell growth similarly to HsPARP1 [96]. Growth inhibition by both proteins was reverted by the addition of the PARP inhibitors $3 \mathrm{AB}$ and 6-(5H)-phenanthridinone [96].

Like AtPARP2, AtPARP1-GFP was found to localize to the nucleus in Nicotiana benthamiana and in Arabidopsis cell suspension culture [92,93]. Additionally, PARP1-GFP was detected in chloroplasts and mitochondria when expressed in Arabidopsis protoplasts [93]. Fusion of the putative AtPARP1 promoter with GUS and RNA hybridization analyses revealed expression of AtPARP1 in the roots, apices of inflorescences, vegetative meristem, and during the late stages of embryo development [93].

Unfortunately, the nomenclature of Arabidopsis PARP1 and PARP2 genes and proteins has been inconsistent in the literature (Table 1). In this review, the following nomenclature is used, which we recently suggested [47]: AtPARP1 refers to the gene At2g31320, and AtPARP2 refers to At4g02390. The nomenclature of mutants of these genes has been likewise inconsistent and redundant. For a unified nomenclature of published mutants, the reader is referred to [47].

So far, less is known about AtPARP3 (At5g22470), which was first identified by Arabidopsis genome analysis. It was mainly expressed in seeds, but also in seedlings and roots of adult plants [93,101,109, 110]. In addition, expression of AtPARP3 was strongly induced (albeit at a low absolute level) in leaves by severe abiotic stress in the form of paraquat, $\mathrm{NaCl}$, high light, or desiccation [104]. PARP3-GFP fusions localized to the nucleus [93,110], and in one study also to the cytosol [93].

Table 1. Previously used and suggested nomenclature for AtPARP1 and AtPARP2 of Arabidopsis thaliana.

\begin{tabular}{ccc}
\hline Reference & At2g31320 & At4g02390 \\
\hline Buggested Nomenclature & AtPARP1 & AtPARP2 \\
Boltz et al. (2014), PLoS One 9: e88872 [97] & AtPARP2 & AtPARP1 \\
Briggs and Bent (2011), Trends Plant Sci. 16: 372-380 [98] & AtPARP2 & AtPARP1 \\
Chen et al. (2018), Front. Plant Sci. 9: 1581 [94] & AtPARP1 & AtPARP2 \\
De Block et al. (2005), Plant J. 41: 95-106 [99] & AtPARP2 & AtPARP1 \\
Doucet-Chabeaud et al. (2001), Mol. Genet. Genom. 265: 954-963 [95] & AtPARP1 & AtPARP2 \\
Jia et al. (2013), Plant Mol. Biol. 82: 339-351 [100] & AtPARP1 & AtPARP2 \\
Feng et al. (2015), PLoS Genet. 11: e1004936 [101] & AtPARP1 & AtPARP2 \\
Keppler et al. (2018), Front Plant Sci. 9: 1907 [102] & AtPARP1 & AtPARP2 \\
Lamb et al. (2012), Cell Mol. Life Sci. 69: 175-189 [103] & AtPARP2 & AtPARP1 \\
Ogawa et al. (2009), Plant J. 57: 289-301 [104] & AtPARP1 & AtPARP2 \\
Pellny et al. (2009), Mol. Plant 2: 442-456 [105] & AtPARP1 & AtPARP2 \\
Pham et al. (2015), Plant Mol. Biol. 89: 319-338 [93] & AtPARP2 & AtPARP1 \\
Rissel et al. (2017), Front. Plant Sci. 8: 59 [47] & AtPARP1 & AtPARP2 \\
Rissel et al. (2017), Anal. Biochem. 527: 20-23 [96] & AtPARP1 & AtPARP2 \\
Schulz et al. (2012), PLoS One 7: e37287 [106] & AtPARP2 & AtPARP1 \\
Song et al. (2015), PLoS Genet. 11: e1005200 [92] & AtPARP1 & AtPARP2 \\
Vanderauwera et al. (2007), PNAS 104: 15150-15155 [107] & AtPARP2 & AtPARP1 \\
Zhang et al. (2015), Sci. Rep. 5:15892 [108] & AtPARP1 & AtPARP2 \\
\hline
\end{tabular}

In contrast to the expression of AtPARP1 in yeast cells, AtPARP2 inhibited yeast growth only partially, while AtPARP3 expression did not affect growth [96]. This may be attributed to differences 
in or lack of the DNA-binding domain in AtPARP2 and AtPARP3. The DNA-binding domain of HsPARP2 is also structurally different from that of HsPARP1, but HsPARP2 expression causes an inhibition of yeast growth [111]. The differential growth inhibition of yeast indicated that Arabidopsis and human PARPs share structural or functional features, but also pointed to plant-specific functions of AtPARP2 and AtPARP3.

\subsection{In Contrast to Mammals, Plants Possess More Than One Poly(ADP-ribose) Glycohydrolase (PARG) Gene}

In total, three genes with homology to human PARG have been identified in Arabidopsis thaliana [109]. For one of them, no expressed sequence tags (ESTs) or cDNA has been found so far. Therefore, this gene is classified as a pseudo-gene. The other two genes, AtPARG1 (At2g31870) and AtPARG2 (At2g31865), are localized in tandem on chromosome 2.

In Arabidopsis, both PARG proteins are localized in the nucleus, the cytoplasm, and at the plasma membrane [101,108]. AtPARG1 (also known as TEJ) was first identified in a genetic screen for altered circadian period length in Arabidopsis [112]. Mutant plants carrying a G262E substitution in the AtPARG1 protein showed a prolonged free-running period regarding the expression of circadian clock-controlled genes and leaf movement. These tej mutants also flowered earlier. These phenotypes suggest a general clock defect, making AtPARG1 a component of clock function in plants. Poly(ADP-ribose) polymer levels were increased in the tej mutants suggesting that AtPARG1 is a bona fide PARG [112]. Poly(ADP-ribose)glycohydrolase activity of AtPARG1 has been validated in vitro and in vivo [101]. Western blot and autoradiography of ${ }^{32} \mathrm{P}_{-} \mathrm{NAD}^{+}$revealed that recombinant AtPARG1 is able to remove poly(ADP-ribose) from automodified AtPARP2. Similarly, co-expression of AtPARP2 and AtPARG1 in Arabidopsis protoplasts led to a significant removal of poly(ADP-ribose) from automodified AtPARP2. In contrast to this, no poly(ADP-ribose)glycohydrolase activity towards automodified AtPARP2 or AtPARP1 was found for AtPARG2 in vitro and in vivo. This lack of activity could not be exclusively attributed to the presence of a polymorphism in the conserved PARG signature motif in PARG2, since a recombinant PARG2 protein carrying the conserved PARG motif did also not show any detectable poly(ADP-ribose) glycohydrolase activity. Therefore, additional deviations in the protein sequence of AtPARG1 and AtPARG2 are thought to account for the differences in enzyme activity [101].

Proteins that possess the ability to hydrolyze the ester bond between the ribose and the acceptor amino acid in Arabidopsis have not been determined yet. However, the proteins encoded by the loci At1g63410, At1g69340, and At2g37710 show considerable homology to the human MacroD1 and MacroD2 proteins described above and are thus candidates for this function. There seem to exist no Arabidopsis proteins homologous to human ARH3 and TARG1.

\subsection{Plant PARPs Play a Role in DNA Damage Response and Genome Integrity}

During about 40 years of work on poly(ADP-ribosyl)ation in plants, various studies showed that plant PARP proteins are components of DNA damage responses similar to their mammalian counterparts. The expression of AtPARP1 and AtPARP2, but not AtPARP3, is induced by treatment with DNA-damaging agents, such as ionizing radiation, zeocin (a radiomimetric drug that induces DSB) or cisplatin (an inhibitor of DNA replication by cross-linking neighboring guanine bases) in Arabidopsis $[95,97,113]$. AtPARP3 expression was only induced in the absence of AtPARP1 or AtPARP2 [97]. In contrast, HvPARP3 expression was induced in barley roots in response to bleomycin (a glycopeptide that mainly induces DSB) [114]. Similar to AtPARP expression, PARP activity was induced by DNA-damaging agents, such as zeocin and X-ray irradiation $[115,116]$. Recombinant AtPARP1 and AtPARP2 are activated by nicked DNA as shown by automodification of the recombinant AtPARP proteins $[91,95,101,116]$. For AtPARP2, automodification was also shown in vivo [101]. Automodification of proteins in vitro and in vivo was blocked by the addition of the pharmacological PARP inhibitor 3 AB $[91,116]$. 
In agreement with increased gene expression and activity, the genetic inhibition of AtPARPs in parp1 and parp2 mutant plants enhanced the sensitivity of plant growth to methyl methane sulfonate (MMS, a DNA alkylation agent that induces N-alkyl lesions and single strand breaks (SSB)) and to bleomycin $[97,100,108,117]$. Similarly, formation of true leaves was reduced in parp 2 seedlings grown on bleomycin and mitomycin C (a DNA cross-linking agent) [92]. Some authors reported that parp2 mutants are more sensitive to DNA-damaging agents than parp1 mutants [92,97]. In line with this, poly(ADP-ribosyl)ation was strongly reduced in parp2, but not in parp1 mutants [92]. Increased plant damage was observed in parp1 parp2 double mutants compared to the corresponding single mutants, indicating that both AtPARP genes are involved in responses to DNA-damaging agents $[92,97,100,108]$. This notion is further supported by an enhanced expression of AtPARP1 in parp 2 mutants and vice versa $[47,92,97]$. Additionally, AtPARP1 and AtPARP2 were shown to physically interact with each other $[92,116]$. No exacerbation in the severity of plant damage was observed in parp1 parp 2 parp 3 triple mutants, indicating that AtPARP3 is not active in DNA damage response in seedlings [108]. However, in barley, HvPARP3 mutation led to an altered root growth response to bleomycin [114]. In summary, plant damage and reduced growth of parp mutants under genotoxic stress may be explained by aggravated DNA damage.

In addition to DNA-damaging agents, infection of plants with the bacterium Pseudomonas syringae pv. tomato (Pst) was shown to induce DNA damage [118]. In line with this, DNA damage was enhanced in parp2 and parp1 parp2 mutants in response to treatment with Pst [92].

\subsubsection{PARP1 and PARP2 Are Actors in Various DNA Damage Response Pathways in Plants}

The exacerbated sensitivity of Arabidopsis parp mutants to various DNA-damaging agents showed that plant PARPs are important actors in DNA damage responses, similar to their human counterparts. In line with this, the ionizing radiation-mediated induction of AtPARP2 was found to depend on the presence of ATM, as the induction was absent in atm mutant plants [119]. ATM is an initiator of various DNA damage repair pathways [120] (see Section 2.2). Yet, the involvement of plant PARP proteins in specific DNA repair pathways still has to be elucidated. For instance, the PARP inhibitor 3-methoxybenzamide (3MB) increased the number of recombination events in Arabidopsis and tobacco [121]. This indicates that PARPs negatively regulate DNA repair by HR. In line with this, expression of the HR components AtRAD51 and AtXRCC 3 was enhanced by $3 \mathrm{AB}$ treatment [122]. Moreover, expression of AtPARP2 was induced in mms21-1 mutant plants, while homologous recombination events were found to be reduced in this mutant [113]. AtMMS21 encodes a SUMO E3 ligase, a critical component of the SMC5/6 complex which fulfills a central role in genome stability maintenance [113]. In contrast, expression of $A t X R C C 2$, another component of HR, was found to be reduced upon $3 \mathrm{AB}$ treatment $[97,122]$. These apparently contradicting findings still have to be elucidated.

Another study indicated that PARPs are involved in an error-prone alternative pathway of NHEJ like their mammalian counterparts [100]. Triple mutant plants lacking AtPARP1, AtPARP2, and AtKu80, a component of classical NHEJ, were more sensitive to MMS than parp1 parp2 and ku80 mutants, indicating that different DNA damage response pathways are impaired in the mutants [100]. Additionally, the extent of DNA damage was higher in the parp1 parp 2 ku 80 mutant plants. A cell-free end-joining assay revealed a higher number of large deletions ( $>10 \mathrm{bp}$ ) at the ends of broken DNA strands in $k u 80$ and parp 1 parp 2 ku 80 than in parp 1 parp 2 mutants. So, resection of nucleotides from the DNA ends occurred mainly in the $k u 80$ and parp 1 parp 2 ku 80 mutants. An alternative NHEJ pathway in $k u 80$ mutants is microhomology-mediated end-joining (MMEJ). A higher level of MMEJ products were found in $k u$ mutants compared to parp1 parp 2 or parp1 parp $2 k u 80$ mutants, indicating that PARPs are involved in MMEJ [100]. In contrast, Shen and colleagues suggested that PARPs act in alternative NHEJ-independent of micro-homology [123].

Recently, one function of AtPARP1 in DNA damage responses was further clarified. A parp1 rad5a double mutant was more sensitive to the DNA-alkylating agent MMS than the corresponding single 
mutant plants [117]. By contrast, parp1 rad5a did not display enhanced sensitivity to the crosslinking agents cisplatin and mitomycin $C$ as compared to the rad5a mutant plants. No enhanced sensitivity to either agent was observed in the parp 1 mutant compared to wild type plants. These findings suggested that AtPARP1 is involved in the repair of base alkylations in a pathway parallel to that involving RAD5a, which possibly corresponds to base excision repair (BER) and HR-independent single strand break repair [117]. In line with this, $3 A B$ repressed paraquat-induced XRCC1 expression [122]. XRCC1 is a component of the gap-filling and nick-sealing step of BER [124]. AtPARP2 expression is induced in the absence of Ligase1, another component of BER, indicating that AtPARP2 also interacts with the BER pathway [91].

\subsubsection{PARP3 Is a Core Component of Genome Integrity in Seeds}

In adult Arabidopsis plants, AtPARP3 was suggested to be either inactive or not involved in DNA damage responses [108]. In contrast, strong expression was found in seeds [101,109]. A screening of publicly available microarray datasets and histochemical GUS analyses confirmed the accumulation of AtPARP3 transcripts specifically in the embryo and the endosperm of dry seeds, during imbibition, and during seed germination [110]. A similar expression pattern was also found for the PARP3 orthologue in rice [125]. In addition, poly(ADP-ribose) levels did not correlate with the depth of seed dormancy in different ecotypes of Arabidopsis, but with their sensitivity to MMS [126,127]. Hence, AtPARP3 was suggested to be involved in protecting the plant embryo from DNA damage in the seed. This notion is supported by the findings that AtPARP3 promoter activity coincided with reactive oxygen species (ROS) accumulation in the embryo and that parp3 mutant seeds lose viability upon prolonged storage or upon artificial ageing, pointing to a role of AtPARP3 in ROS-induced DNA damage responses during seed storage and germination $[110,128]$. Database searches reveal the presence of sequences homologous to AtPARP3 in other plant species, such as Populus trichocarpa, Physcomitrella patens, Oryza sativa, Brachypodium distachyon, Sorghum bicolor, Zea mays, and Hordeum vulgare $[110,114,125]$. This leads to the conclusion that the protective role of PARP3 may be conserved throughout the plant kingdom.

The activity of PARPs produces the feedback inhibitor nicotinamide as byproduct [7]. Nicotinamidases convert nicotinamide to nicotinate, which is further metabolized back to $\mathrm{NAD}^{+}$ in the salvage pathway [7]. In Arabidopsis, the expression pattern of AtPARP3 correlates with that of Nicotinamidase 2 (NIC2) [126]. Germination of nic2 mutant seeds was hypersensitive to MMS, potentially due to reduced levels of poly(ADP-ribosyl)ation, which are, in turn, likely to be due to a reduced nicotinamide degradation $[126,127]$. On the other hand, overaccumulation of nicotinate from nicotinamide degradation is toxic. Consequently, nicotinate detoxification by O-glycosylation, mediated by the nicotinate glycosyltransferase UGT74F2-1, has been shown to be required for seed germination under stress [129]. This is further evidence for the induction of PARP3 activity in seeds under unfavorable conditions.

Since AtPARP3 shows structural homologies to AtPARP1 and human PARP3 (Figure 2), similar functions may be assumed. As discussed above (Section 2.2), human PARP3 is involved in non-homologous end-join (NHEJ) repair of DNA damage, suggesting a role of plant PARP3 in DSB repair via NHEJ. Interestingly, in Hordeum vulgare, expression of HvPARP3 in young seedling roots was enhanced by the DNA DSB-inducing agent bleomycin [114], supporting such a function. Yet, the exact role of plant PARP3 in DNA DSB repair has to be elucidated. Besides germination of Arabidopsis parp3 mutant seeds in the presence of DNA DSB-inducing agents, crossing of parp3 mutants with $k u 70$ and $k u 80$ mutants may provide evidence whether AtPARP3 acts in NHEJ like its mammalian counterpart. Since direct evidence of poly(ADP-ribosyl)ation activity of AtPARP3 is lacking so far, PARP activity needs to be determined in parp3 mutant seeds. Aberrant poly(ADP-ribose) levels will indicate whether AtPARP3 is capable of poly(ADP-ribosyl)ation. However, a mono(ADP-ribosyl)ation activity by this enzyme, similar to its human counterpart, is also conceivable. 


\subsubsection{Like PARPs, Plant PARG Proteins Are Linked to DNA Damage Response}

Similar to parp mutant plants, Arabidopsis parg1 mutants exhibited enhanced sensitivity to mitomycin C and bleomycin [130]. Mutant plants lacking AtPARG2 displayed no or only slightly increased sensitivity to DNA-damaging agents, indicating that AtPARG1 is more important in the response to DNA damage caused by DNA-damaging agents $[108,130]$. Notably, parg1 mutations induced more severe plant damage than the lack of AtPARPs [108]. This was attributed to the fact that free poly(ADP-ribose) is thought to be toxic to plant cells, as it has been described for mammalian cells [108].

The mechanistic role of PARGs in DNA damage responses of plants still has to be elucidated. Enhanced expression of HR components (i.e., SMC6A, SMC6B, RAD17, RAD51, RAD54, REV7) and NHEJ components (i.e., LIG4, Ku70, Ku80) was found in parg1 mutants [108]. In contrast, RAD51 and SWI expression induced by the bacterial elicitor flg22 were disrupted in parg1 mutants [131]. Apart from that, induction of AtPARG1 expression was attenuated in atm and atr mutant plants and vice versa [108]. Similar to ATM, ATR is an initiator of various DNA damage repair pathways [120]. Hence, PARGs, like PARPs, appear to act as a switch between different DNA repair pathways in planta. Yet, their exact function is still ambiguous.

\subsubsection{Similar to Their Human Counterparts, Plant PARPs Are Capable of Chromosome Modification}

In line with a role in plant DNA damage response, PARPs have a poly(ADP-ribosyl)ating activity on chromosomal proteins. AtPARP1 and AtPARP2 associate with chromosomes in dividing cells via their N-terminal domains [132]. Thereby, both proteins co-localize and probably compete for suggested heterochromatin association sites. Histones H1, H2A, and H2B in wheat and tobacco and histones H1.1 and $\mathrm{H} 1.3$ in Arabidopsis were targeted by poly(ADP-ribosyl)ation, putatively creating a chromatin structure more accessible to RNA polymerase II, as found for human PARP1 [86,87,101]. A potential transcriptional regulation by PARP proteins is indicated by the interaction of AtPARP1 with DIP1 and DIP2, two proteins homologous to the transcriptional coactivator ALY, via its DNA-binding domain in vitro and in yeast [133].

Expression of AtPARP1 and AtPARP2, but not AtPARP3, is increased in response to telomerase dysfunction [97,134]. However, in contrast to their human counterparts, AtPARP1 and AtPARP2 do not stimulate telomerase activity. Apart from this, neither Arabidopsis PARP is involved in telomere end protection and telomere length protection in seedlings and flowers [97]. In contrast, HvPARP3 was suggested to be involved in telomere length maintenance in barley seedlings [114]. This apparent discrepancy calls for a systematic study of telomere-related roles of PARPs in a greater diversity of plant species.

\subsection{Plant PARPs Play Diverse Roles in Cell Death, Development, and Metabolism}

Mammalian PARP proteins are regulators of various facets of cell death (see Section 2.2). Comparable functions have also been found for plant PARPs $[135,136]$. Thus, treatment with the PARP inhibitors, $3 \mathrm{AB}$ and nicotinamide, blocked heat shock- and $\mathrm{H}_{2} \mathrm{O}_{2}$-induced PCD in cultured tobacco and soybean cells, whereby the PARP inhibitor-mediated protection from $\mathrm{H}_{2} \mathrm{O}_{2}$-induced $\mathrm{PCD}$ was most effective during the initial phase of $\mathrm{H}_{2} \mathrm{O}_{2}$ treatment $[135,136]$. At that point, a sharp drop in $\mathrm{NAD}^{+}$levels in the soybean cells indicated the onset of PARP activity. Interestingly, overexpression of AtPARP2 in soybean cell culture resulted in reduced cell death at low concentrations of $\mathrm{H}_{2} \mathrm{O}_{2}$ (mild oxidative stress), but a dramatically increased cell death at high $\mathrm{H}_{2} \mathrm{O}_{2}$ concentrations (severe oxidative stress). In addition, AtPARP2 expression reduced the amount of nicked DNA under both mild and severe oxidative stress [135]. Additionally, cleavage of AtPARP proteins by Caspase-3, a central component of programmed cell death, was demonstrated in tobacco cells directly after PCD-inducing heat shock treatment [136]. These findings suggest that plant PARPs fulfill similar 
functions as their mammalian counterparts: They act as a switch between DNA damage repair under mild stress conditions and PCD under severe stress conditions.

Apart from DNA damage and PCD, PARP proteins and poly(ADP-ribosyl)ation have been proposed to play an important role in plant development [137]. For example, the formation of tracheary elements in artichoke cell cultures, artichoke tubers, and pea root explants was inhibited by addition of the PARP inhibitor, 3AB [138]. In addition to this, AtPARP1 and AtPARP2 expression and their activity increased in Arabidopsis cell cultures during the exponential growth phase [105]. This increase in expression and activity was temporally linked to an increase in marker gene expression for $S$ to G2 phase transition in the cell cycle. Simultaneously, there was a correlation between the increase in PARP activity and an increase in the glutathione pool during exponential growth of the cell culture [105]. Hence, PARP activity is linked to cell cycle progression and redox regulation, suggesting a regulatory function of AtPARPs in plant development. In line with this, seed germination was altered in parp1, parp2, and parp3 mutant plants. Under non-stressed conditions, parp3 plants germinated faster than the wild type, while parp 1 and parp 2 exhibited slower and partially reduced germination rates [93].

In addition to germination, plant growth regulation appears to involve poly(ADP-ribosyl)ation, since the PARP inhibitor 3MB has been shown to improve Arabidopsis growth under non-stressed conditions $[106,139]$. Enhanced growth by $3 \mathrm{MB}$ was attributed to higher leaf cell numbers due to a shortened cell division cycle, resulting in an increased overall leaf size [139]. Moreover, 3MB treatment altered gene expression in Arabidopsis plants under unstressed conditions, affecting components of plant responses to external and internal stimuli and abiotic stress response, circadian rhythm, plant growth, energy metabolism and photosynthesis, and primary and secondary metabolism [106,131,139]. For the PARP inhibitor $3 \mathrm{AB}$, contrasting effects have been reported, depending on the $3 \mathrm{AB}$ concentration used. Biomass of Arabidopsis plants was reduced upon treatment with 2.5 or $5 \mathrm{mM}$ 3АB $[97,131,140]$, whereas $1 \mathrm{mM} 3 \mathrm{AB}$ promoted plant biomass and root system development, resulting in more lateral roots, formation of secondary order lateral roots, increased lateral root length, and increased primary root length compared to the control plants [116]. Similar, although weaker, effects were observed for another PARP inhibitor, $6(5 \mathrm{H})$-phenanthridinone. Similar to pharmacological PARP inhibition, the absence of AtPARP1 and AtPARP2 in parp1 parp2 double mutant plants led to the formation of a larger root system compared to the wild type [116], but this phenotype was weaker than that caused by the inhibitors. In contrast, in a recent study by our lab, knockout mutant lines of all Arabidopsis PARP genes, including all double mutant combinations and a parp1 parp 2 parp 3 triple mutant, did not display obvious developmental alterations under non-stress growth conditions [47]. This is consistent with findings obtained by other authors $[92,108,116]$. Hence, PARPs seem to have an effect on plant development only under specific conditions the nature of which needs yet to be defined. Furthermore, the stronger and more consistent effects or PARP inhibitors, as compared to genetic knockout, points to off-target effects of those substances. Further work is required to elucidate the specific role of PARPs in plant development.

\subsection{Poly(ADP-Ribosyl)ation and Plant Responses to Abiotic Stress}

PARP proteins of plants have been associated with responses to abiotic stress. In some studies, the expression of AtPARP and AtPARG genes was altered in response to abiotic stresses [95,104], albeit numerous other studies failed to detect transcriptional responses to drought, osmotic, or salt stress [47,141-147]. Knockdown of PARP1 or PARP2 in oilseed rape and Arabidopsis by PARP hairpin constructs enhances the tolerance to desiccation, short-term paraquat treatment, and high light, associated with a reduced PARP activity under stress [99]. Accordingly, high energy consumption, which is a response to PARP activation following severe stress in mammalian cells, was prevented in the knockdown lines. Energy homeostasis and normal levels of mitochondrial respiration were maintained, and ROS production was kept low [99]. Hence, energy preservation under stress was suggested as a cause of the enhanced abiotic stress tolerance of $P A R P$ knockdown lines. Additional explanations 
were provided by a transcriptomic study on plants with reduced AtPARP1 expression [107]. Under "high light" stress (250-300 $\left.\mu \mathrm{mol} \mathrm{m}^{-2} \mathrm{sec}^{-1}\right)$, AtPARP1 knockdown led to an attenuated expression of temperature-responsive and oxidative stress-dependent genes. Furthermore, genes involved in cellular transport and energy metabolism were repressed, again supporting the hypothesis that reduced PARP activity enhanced stress tolerance by reducing oxidative stress and preserving energy homeostasis. In contrast, genes responsive to abscisic acid (ABA), dehydration, and cold were hyper-induced by AtPARP1 knockdown under high light stress [107]. Simultaneously, ABA levels were observed to be higher in the plants exhibiting reduced AtPARP1 expression. These findings pointed to a role of AtPARP1 as a negative transcriptional regulator of plant stress responses in an ABA-dependent way. This provoked an additional hypothesis to explain the enhanced abiotic stress tolerance by reduced PARP activity, linking the increased $\mathrm{NAD}^{+}$levels to the increased ABA levels and the increased expression of ABA-responsive genes via cyclic ADP-ribose (cADPR) [107]. This molecule is synthesized by an unknown ADP-ribose cyclase using $\mathrm{NAD}^{+}$as a substrate, and it is involved in ABA-dependent stress signaling, as well as in the regulation of the circadian clock [109,148-150]. cADPR triggers the release of $\mathrm{Ca}^{2+}$ from internal stores, which induces ABA production and hence ABA-responsive gene expression. It was hypothesized that the preservation of the $\mathrm{NAD}^{+}$pool by a reduction in AtPARP1 expression promotes CADPR synthesis, thereby conferring enhanced stress tolerance. Albeit the synthesis of CADPR, its activity as $\mathrm{Ca}^{2+}$-releasing second messenger, and its involvement in $\mathrm{ABA}$ and nitric oxide signaling have individually been demonstrated in plants [150-154], the underlying molecular mechanisms remain largely obscure since neither homologs of animal ADP-ribose cyclases nor those of animal cADPR-activated $\mathrm{Ca}^{2+}$ channels (e.g., ryanodine receptors) are present in higher plants [155]. The testing of this hypothesis therefore poses a formidable task.

The notion of plant PARPs as important negative factors of abiotic stress tolerance has been challenged by a recently reported study, wherein growth of Arabidopsis single, double, and triple knockout mutants for all three AtPARP genes was unchanged from the wild type when exposed to desiccation, salt, osmotic, or oxidative stress [47]. These opposing results lead to the conclusion that the enhanced stress tolerance phenotype is conditional. Conditional phenotypes occur frequently in loss-of-function mutants, since plants have evolved many adaptive traits that allow them to cope with changes in their environment [156]. Factors accounting for conditional phenotypes can be light, temperature, and nutritional status, and interactions among them are possible [156]. Accordingly, a large number of conditional phenotypes have been described in loss-of-function mutants which affect all aspects of plant development [157]. For instance, the conditional root expansion mutant quill shows similar root growth as the wild type on $0.5 \%$ sucrose, but dramatically reduced root growth on $4.5 \%$ sucrose medium. Under these conditions, root growth of wild type plants is even pronounced [158]. Similarly, the petit1 mutant shows reduced hypocotyl elongation on sucrose-containing medium, but not on sucrose-free medium [159]. The photoperiod-insensitive early-flowering 3 mutant elf3 shows rhythmic leaf movement in the dark and under several light/dark regimes, but not under constant light [160]. Not only the light regime, but also the light intensity, can affect plant phenotypes. Consequently, vad1 mutants show hypersensitive response-induced lesions under high, but not under low, light intensities [161]. In contrast, plants lacking the Myeloblastosis (MYB) domain-containing proteins MYB33 and MYB65 exhibit male sterility specifically under low light conditions [162]. These examples illustrate the wide range of conditional phenotypes identified so far in plant research using loss-of-function mutant lines.

Compared to genetic PARP inhibition, pharmacological PARP inhibition has been widely used as a tool to elucidate the role of PARP proteins in plant stress tolerance [99,106,122,139,163]. Energy homeostasis in plants was improved by 3MB-mediated PARP inhibition. While the expression of genes related to photosynthesis, the effective photosynthetic quantum yield, and the electron transport rate were induced, low-energy-status marker genes were unaltered in Arabidopsis plants grown in unstressed conditions [139], and $\mathrm{NAD}^{+}$content was increased under both unstressed and oxidative stress conditions [106]. Notably, 3MB treatment de-regulated gene expression of components of the 
phenylpropanoid pathway under unstressed and oxidative stress conditions $[106,139]$. The abundance of metabolites derived from the phenylpropanoid pathway, such as flavonols and lignins, decreased upon 3MB treatment [139]. These findings can explain reduced leaf pigmentation, reduced anthocyanin accumulation, and enhanced plant growth observed upon 3MB treatment under paraquat-induced oxidative stress [106]. Reduction of anthocyanin accumulation was not specific to $3 \mathrm{MB}$, as the PARP inhibitors 3-methylbenzamide and 3-aminophthalhydrazide acted similarly. Additionally, concentrations of other stress-related metabolites, such as galactinol or myo-inositol, were reduced by the inhibitors. Apart from its interference in oxidative stress responses, 3MB enhanced plant growth in response to salt, heat, and high-light stress [106]. Additionally, 3MB and nicotinamide enhanced the tolerance of Brassica napus hypocotyl explants to oxidative stress elicited by acetyl salicylic acid [99]. In another study, the PARP inhibitor 4-amino-1,8-naphthalamide enhanced growth rates of Lemna minor facing osmotic stress by polyethylene glycol treatment $(-0.3 \mathrm{MPa})$ and tolerance of an Arabidopsis cell culture to $\mathrm{H}_{2} \mathrm{O}_{2}$ [163]. In contrast to the finding that the pharmacological inhibition of PARP reduced plant sensitivity to paraquat treatment [99], other authors found that 3AB treatment of Arabidopsis seedlings enhanced the sensitivity to long-term paraquat treatment [122]. This discrepancy might be explained by different levels of stress and the resulting extent of PARP activation.

\subsection{Poly(ADP-Ribosyl)ation and Plant Responses to Biotic Attack}

Pathogen-associated molecular patterns (PAMPs) are structural or functional units of a microbe that are recognized by the plant immune system and elicit defense responses. The $\mathrm{N}$-terminally conserved 22 amino acids of flagellin (flg22) from Pseudomonas bacteria and the N-terminal 18 amino acids of EF-Tu (elf18) from Escherichia coli are such PAMPs. They elicit immune responses such as oxidative burst, elevation of cytosolic free $\mathrm{Ca}^{2+}$, cell wall reinforcements by callose and lignin, and transcriptional induction of defense genes [164-166]. The PARP inhibitors 3AB and 6-(5H)-phenanthridinone block flg22- and elf18-induced callose deposition in Arabidopsis seedlings $[47,102,130,140]$, albeit transcript and protein induction of the callose synthase gene are not affected [102]. This effect can be bypassed by salicylic acid [130]. No alterations upon PARP inhibitor treatment were found in early PAMP responses, such as ROS burst, and in wounding-induced callose deposition $[102,130]$. In contrast to $3 \mathrm{AB}$ and $6(5 \mathrm{H})$-phenanthridinone, the potent PARP inhibitors PJ-34, INH2BP, and 4ANI did not block PAMP-induced callose deposition $[47,102]$, which may be explained by off-target effects of the drugs.

A number of other pharmacological studies have assigned PARPs a role as regulators of pathogen responses. For example, the PARP inhibitor $3 \mathrm{MB}$, which is structurally very similar to $3 \mathrm{AB}$, has been shown to negatively influence the phenylpropanoid pathway $[106,139]$. Similar observations were also made for $3 \mathrm{AB}$, which inhibited phenylalanine ammonium lyase, a component of the phenylpropanoid pathway [167]. Likewise, elf18-induced guaiacyl-lignin accumulation was blocked upon $3 A B$ treatment [130]. Transcriptomic analyses further revealed that pharmacological PARP inhibition by $3 \mathrm{AB}$ de-regulated PAMP-induced transcriptional responses in Arabidopsis [131].

Contrary to pharmacological PARP inhibition by $3 \mathrm{AB}$ and 6- $(5 \mathrm{H})$-phenanthridinone, genetic abolishment of AtPARP1 or AtPARP2 in T-DNA single knockout lines did not alter flg22-induced callose deposition, whereas in two studies parp1 parp2 double mutant lines exhibited enhanced or reduced callose deposition, depending on the plant age and/or flg22 concentration applied [92,168]: The transfer of five-day-old seedlings to liquid medium containing $1 \mu \mathrm{M}$ flg22 enhanced callose deposition (but not the ROS burst) [92], while infiltration of leaves of four-week-old plants with $0.5 \mu \mathrm{M}$ flg22 reduced this response [168]. Nevertheless, parp 2 mutant plants and parp1 parp 2 double mutant plants displayed enhanced sensitivity towards the Pst strain DC3000 [92,101]. This strain also induced an activation of PARP in Arabidopsis plants, as demonstrated by reduced cellular NAD ${ }^{+}$levels and increased leaf poly(ADP-ribose) content [130]. Taken together, these findings point to a role of PARP proteins, particularly PARP2, as regulatory components of the basal immune response. However, in two independent recent studies, flg22-induced callose deposition was not altered in parp1 parp 2 parp3 
triple knockout seedlings [47,102]. In the two studies, the plants differed in their developmental stage and their growth conditions at the time of flg22 application. Hence, these contrasting findings further support the above-raised notions of a conditionality of the parp mutant phenotypes and of off-target effects of PARP inhibitors, which remain to be tested experimentally.

A new actor in PARP-mediated plant immunity has been identified recently. Mutant plants lacking the AtPARP2-poly(ADP-ribosyl)ated protein DWADLE (DDL) exhibited an exacerbated sensitivity to Pst DC3000, P. syringae pv. maculicola, non-pathogenic Pst DC3000 hrcC (a type III secretion mutant of Pst DC3000), and non-adaptive pathogen P. syringae pv. phaseolicola [168]. Similarly, ddl mutants showed reduced callose deposition in response to flg22 and Pst DC3000 hrcC. In contrast to pharmacological PARP inhibition, early PAMP-induced gene expression was reduced in parp1 parp 2 mutants, but not in $d d l[101,168]$; late transcriptional responses to PAMP treatment were reduced in both parp1 parp2 and $d d l$ [168]. These partially overlapping phenotypes of parp1 parp2 and $d d l$ further indicated an interaction of these proteins in response to PAMPs. In fact, an interaction of AtPARP2 and DDL was confirmed by immunoprecipitation and bimolecular fluorescence complementation assays, and found to be enhanced by flg22. The direct interaction of both proteins was markedly stronger upon poly(ADP-ribosyl)ation. In addition to AtPARP2, AtPARP1 was also shown to poly(ADP-ribosyl)ate DDL, but to a lesser extent than AtPARP2. A DDL protein lacking its poly(ADP-ribosyl)ation sites was unable to complement the susceptibility to PAMP treatment, indicating that poly(ADP-ribosyl)ation of DDL is essential for proper plant immune response. As DDL enhances late PAMP-induced gene expression, and as it was suggested to interact with histone acetyltransferases in Arabidopsis, Feng and colleagues concluded that DDL is involved in poly(ADP-ribosyl)ation-mediated chromatin remodeling to allow access to target gene promoters during plant immunity [168].

Since PARGs antagonize PARP action, parg mutants should also display altered responses to biotic attack. Accordingly, parg1 but not parg2 mutants displayed a more severe growth inhibition upon elf18 treatment accompanied by an enhanced pigment accumulation [130]. Mature parg1 plants also displayed enhanced flg22-induced callose deposition and increased expression of flg22-regulated genes [101]. Similar to parp mutant plants and pharmacological PARP inhibition, the early PAMP-induced ROS production was not altered in the parg1 mutant plants. Nevertheless, this mutant displayed transcriptional changes in defense gene expression [131]. These changes could not be assigned to specific pathogen-induced signaling pathways, leading to the conclusion that AtPARG1 acts as a regulatory element at response pathway junctures [131]. Apart from this, the onset of symptoms of B. cinerea infection was accelerated in both parg1 and parg2 mutant plants [130]. Hence, particularly AtPARG1 can be described as a positive regulator of biotic stress responses. Against this background, it is surprising that AtPARG2 expression was up-regulated in response to Pst and Botrytis cinerea infection and flg22 treatment, while AtPARG1 was only transiently induced by treatment with flg22 and elf18 $[92,130,140]$. This discrepancy needs to be elucidated.

\subsection{Non-Canonical PARP Domain Proteins Act in Plant Stress Responses}

In addition to the canonical PARP proteins, members of the SRO (Similar to RCD One) family possess a catalytic PARP domain, albeit with an unusual catalytic triad motif $[169,170]$. Therefore, SRO proteins can be regarded as part of the plant PARP family sensu lato. SRO genes are present in all sequenced land plant genomes, with considerable variation in composition between the sequenced plant species [170-172]. In Arabidopsis, the family comprises the proteins Radical-induced Cell Death1 (RCD1) and its homologues SRO1 through SRO5 [170,173]. In contrast to the canonical PARP proteins, the close homologues RCD1 and SRO1 contain a central catalytic PARP domain which is flanked by an N-terminal WWE domain and a C-terminal RST domain, while SRO2 through SRO5 lack the WWE domain (Figure 2) [169,174]. In in vitro assays, RCD1 is not enzymatically active [170], whereas, intriguingly, PARP activity has been demonstrated in vitro and in vivo for a homologous protein from wheat [175]. 
RCD1 is the first recognized member of this protein family. It was initially identified during screenings for ozone sensitivity in Arabidopsis and oxidative stress regulators in yeast $[173,176]$. Accordingly, Arabidopsis rcd1 mutant plants were hypersensitive to ozone treatment and the resulting apoplastically-produced ROS $[169,176]$. In contrast, $r c d 1$ plants are resistant to ROS formed in the chloroplasts upon paraquat treatment $[169,177]$. $R C D 1$ is expressed ubiquitously and constitutively in Arabidopsis plants $[174,178]$. It localizes to the nucleus $[179,180]$, but upon salt and oxidative stress, RCD1 is also localized in the cytoplasm [180]. RCD1 has been shown to be involved in responses to salt stress, in pathogen defense, in the regulation of stomatal conductance, in UV-B responses, in temperature responses, in $\mathrm{PCD}$, in redox regulation, and in ROS and plant hormone signaling $[169,177,180-190]$. Interestingly, RCD1 is the target of an effector protein of the oomycete pathogen Hyaloperonospora arabidopsis, and binding of this effector suppresses the activation of salicylic acid-induced defense genes and alters light responses [184]. RCD1 is phosphorylated, likely by interacting with Mut9-like protein kinases that also phosphorylate photoreceptors. This may present a link of photoresponse and salicylic acid signaling [184]. Rcd1 mutant plants show severe developmental defects, such as stunted growth, altered rosette and leaf morphology, early flowering time, and a high number of differentially regulated genes $[169,174,178]$. The RCD1 protein interacts physically with the $\mathrm{Na}^{+} / \mathrm{H}^{+}$antiporter SOS1 and in particular with transcription factors from various families, such as AP2/ERF, NAC (NAM, ATAF1 and -2, and CUC2), MYB, and basic helix-loop-helix $[173,174,180,191]$. The most prominent transcription factor RCD1 interacts with is the AP2/ERF family protein DREB2A [173,174,192], which is a transcriptional regulator of genes involved in the responses to various stresses, such as drought, salinity, and heat, and which is also involved in plant senescence [192,193]. This interaction is mediated by the approximately 70 amino acids long, helically-structured C-terminal RST domain [174,190,194,195]. The term "RST" is named after the three proteins carrying this domain: RCD1, SRO1, and TAF4 [194]. In DREB2A, binding to RCD1 is conferred by the RCD1-interacting motif (RIM), albeit the RIM sequence is not sufficient for this interaction [192]. In other transcription factors interacting with RCD1, this motif is absent, and no common motif sequence has been identified conferring the interactions [192,196]. Instead, interaction between RCD1 and its transcription factor partners is mediated by intrinsically disordered regions [197]. Accordingly, short linear motifs of disordered transcription factor regions were found to be sufficient for RCD1 interactions [196]. In summary, the PARP domain protein RCD1 appears to be a central hub in plant stress and pathogen responses, ROS homeostasis, plant hormone signaling, and PCD.

The PARP domain protein SRO1 shares $76 \%$ similarity with RCD1. Both proteins were identified to be paralogs likely arising from a gene duplication [178]. They both localize to the nucleus and are both expressed ubiquitously throughout the plant $[174,178,198]$, whereby expression levels of SRO1 are generally lower than those of RCD1 [178]. In contrast to $r c d 1$ mutant plants, sro1 plants did not exhibit sensitivity to ozone and salt stress, and grew normally under unstressed conditions [174,178]. Similar to RCD1, SRO1 interacted with transcription factors, but only with a subset of those interacting with RCD1 [174]. Double mutants lacking both RCD1 and SRO1 showed detrimental developmental defects $[174,178,198]$. Collectively, RCD1 and SRO1 appear to be unequally redundant proteins [174].

Another member of the SRO family is SRO5. In contrast to RCD1 and SRO1, which show hardly any changes in their expression upon stress, SRO5 transcript levels changed upon salinity, ozone, light, wounding, anoxia, and bacterial elicitors $[170,199]$. Additionally, SRO5 was shown to be involved in the response to salt and oxidative stress in a very peculiar way [200]: upon salt stress, SRO5 transcripts form siRNAs with a gene overlapping in antisense orientation, $P 5 C D H$ (1-pyrroline-5-carboxylate dehydrogenase), thus regulating it at the post-transcriptional level. Surprisingly, expression of the P5CDH gene was not enhanced in sro5 mutant plants $[170,199]$. Apart from this, SRO5 and P5CDH did not overlap in Arabidopsis lyrata, grapevine, and poplar [170]. It was therefore proposed that the regulation of $P 5 C D H$ is not a primary function of the SRO5 gene [170,199]. SRO5 itself is apparently involved in ROS regulation [200]. Similar to RCD1 and SRO1, SRO5 localized to the nucleus and 
interacted with transcription factors, including DREB2A [170], providing an alternative explanation for SRO5 action in planta. Similar to SRO5, SRO2 and SRO3 showed changes in their transcript levels in response to light, salt and ozone [170].

The central position of the SRO family in signaling and stress responses also holds true for monocots. The modulation of ROS homeostasis and a positive role in abiotic stress resistance have been demonstrated for a wheat homolog of RCD1/SRO1, Ta-SRO1 [175]. An SRO protein in rice, OsSRO1c, which is a target of a NAC transcription factor, is also involved in the resistance to oxidative stress, stomatal regulation, and resistance to drought and cold [171,201]. Like Arabidopsis RCD1 and SRO1, this rice protein interacts with DREB and NAC transcription factors [201]. Interaction with a NAC transcription factor was also shown for a barley homolog, HvRCD1 [191]. Another OsSRO family member, OsSRO1a, interacts with an RNA-binding domain protein, OsRBD1 [202]. Co-expression of both proteins in yeast resulted in improved growth under abiotic stress conditions, but a decreased tolerance to oxidative stress [202]. Recently, six SRO proteins have been identified in maize $[203,204]$. The promoter regions of the genes encoding these proteins contain stress-related and hormonal signaling-related elements. Accordingly, expression of $\mathrm{ZmSRO}$ genes was differentially affected by stress and hormone treatments [203,204].

Even though research on SRO proteins has mostly focused on Arabidopsis and monocotyledonous crop species, members of the family have recently been described in other dicotyledonous species. The tomato protein Sl-SRO11, most similar to AtSRO5, improved salt tolerance when expressed in Arabidopsis [199], and the RCD1 protein from lily interacted with the DREB2 transcription factor LIDREB2B, similar to its Arabidopsis ortholog [205].

\subsection{Potential Off-Target Effects of PARP Inhibitors}

In addition to their function in DNA damage responses (see Section 3.3), plant PARPs have been suggested before to be modifiers of plant development, robust negative regulators of plant abiotic stress responses and as positive factors of PAMP-triggered immunity (see Sections 3.4-3.6). This is largely based on studies employing pharmacological PARP inhibition, which appears to modify plant responses to stress, and also plant growth and development under unstressed conditions, more frequently and consistently than genetic PARP knockout $[47,99,102,106,139,163]$. This provokes the idea that pharmacological PARP inhibitors do not only affect the activity of canonical PARPs, but also have off-target effects in planta. In this respect, it is of note that many PARP inhibitors act unspecifically against diverse members of the PARP and tankyrase family in humans [206]. In Arabidopsis, the notion of promiscous PARP inhibitor activity is supported by the finding that protein poly(ADP-ribosyl)ation was not abolished in a parp triple mutant [47], which may be explained by other enzymes also possessing this activity. Proteins belonging to the SRO family may represent such potential alternative inhibitor targets since they contain a catalytic PARP domain. In silico analysis revealed that the PARP inhibitors $3 \mathrm{AB}$ and 6-(5H)-phenanthridinone may bind to this domain [47], whereas a recent study indicated that 6-(5H)-phenanthridinone does not bind to the catalytic PARP domain of RCD1 in the way it binds to human PARP1 [184]. Nevertheless, PARP inhibitors may have a disruptive role in RCD1 function and a yet undefined interaction with the catalytic PARP domain is still conceivable. The unequally redundant proteins, RCD1 and SRO1, as well as the SRO5 protein, have been reported repeatedly to be important actors in plant stress responses. This complex involvement of SRO proteins in stress responses matches the commonly observed changes in stress responses by pharmacological PARP inhibitors.

The notion that PARP inhibitors have off-target effects is further supported by a recent transcriptomic study in which, under standard growth conditions, a treatment with the established PARP inhibitors $3 \mathrm{AB}$ and $3 \mathrm{MB}$ altered the expression of 228 and 3935 genes, respectively [131]. This difference of one order of magnitude makes it highly unlikely that the effects are caused by the inhibition of canonical PARP proteins alone. 
Due to the potential off-target effects, the use of pharmacological PARP inhibitors to infer PARP function in plants should be reconsidered. As a first step to identify additional targets of those drugs, pull-down experiments using the pharmacological "PARP inhibitors" as bait may be a suitable approach.

\section{PARPs Under Stress-Concluding Remarks and Future Perspectives}

In their natural habitat, plants are under the constant threat of biotic and abiotic stressors. Global warming is proposed to increase these threats, endangering future food security. The inhibition of PARPs by genetic or pharmacological means has been suggested as a promising approach to sustain crop yields and hence food security, since PARP inhibition has been found to improve plant performance under abiotic stress. However, the positive effects of PARP inhibition are not as robust as initially suggested, since it has become apparent that the stress-related phenotypes of parp mutants are of a conditional nature. This now calls for an extensive systematic analysis of growth conditions and plant developmental stages to identify the circumstances under which PARP modification causes an alteration of stress responses.

The currently available data therefore suggest that inhibition of canonical PARPs may not be a way forward to stabilize food security. Moreover, PARP inhibition has been shown to exert negative effects on pathogen resistance mechanisms. However, simultaneous or sequential occurrence of abiotic and biotic stress elicits tailored physiological and transcriptional responses that differ from those to single stressors. Accordingly, abiotic and biotic stressors have been reported numerously to have either additive effects, i.e., increasing plant stress level and symptoms, or antagonizing effects, i.e., increasing resistance to one of the stressors [207-209]. For their general roles in genome stability and stress responses, canonical PARPs and SROs may be determinants in the coordination of plant responses to multiple stresses. To test this idea, the response to the combined appearance of abiotic and biotic stressors ought to be studied in plants with altered genetic setup of PARPs/SROs or pharmacologically-altered PARP activity.

In this respect, it is an important future task to experimentally determine the potential additional targets of PARP inhibitors, as this may allow the design of specific inhibitors targeting those proteins. They may be of use in future crop improvement strategies, as the beneficial activities of canonical PARPs would not be affected. Finally, to better understand the mechanistic role of PARP domain proteins in stress responses, the identity of poly(ADP-ribosyl)ated proteins and poly(ADP-ribose)-binding proteins needs to be elucidated.

Author Contributions: Conceptualization, D.R. and E.P.; writing-original draft preparation, D.R.; writing-review and editing, D.R. and E.P.; funding acquisition, E.P.

Funding: This work was funded by the Ministry of Education of the Federal State of Sachsen-Anhalt (grant no. $7703650 \mathrm{D})$ and the Agrochemisches Institut Piesteritz e.V. We acknowledge the financial support within the funding programme Open Access Publishing by the German Research Foundation (DFG).

Conflicts of Interest: The authors declare no conflict of interest. The funders had no role in the design of the study; in the collection, analyses, or interpretation of data; in the writing of the manuscript, or in the decision to publish the results.

$\begin{array}{ll}\text { Abbreviations } \\ \text { 3AB } & \text { 3-aminobenzamide } \\ \text { ADP-ribose } & \text { Adenosine diphosphate ribose } \\ \text { ALY } & \text { Ally of AML-1 and LEF-1 } \\ \text { 4-ANI } & \text { 4-amino-1,8-naphtalimde } \\ \text { AP2/ERF } & \text { APETALA2/ethylene response factor } \\ \text { APP } & \text { Arabidopsis thaliana homologue of PARP } \\ \text { ARH3 } & \text { ADP-ribose hydrolase 3 } \\ \text { ATM } & \text { Ataxia telangiectasia-mutated } \\ \text { ATP } & \text { Adenosine triphosphate }\end{array}$




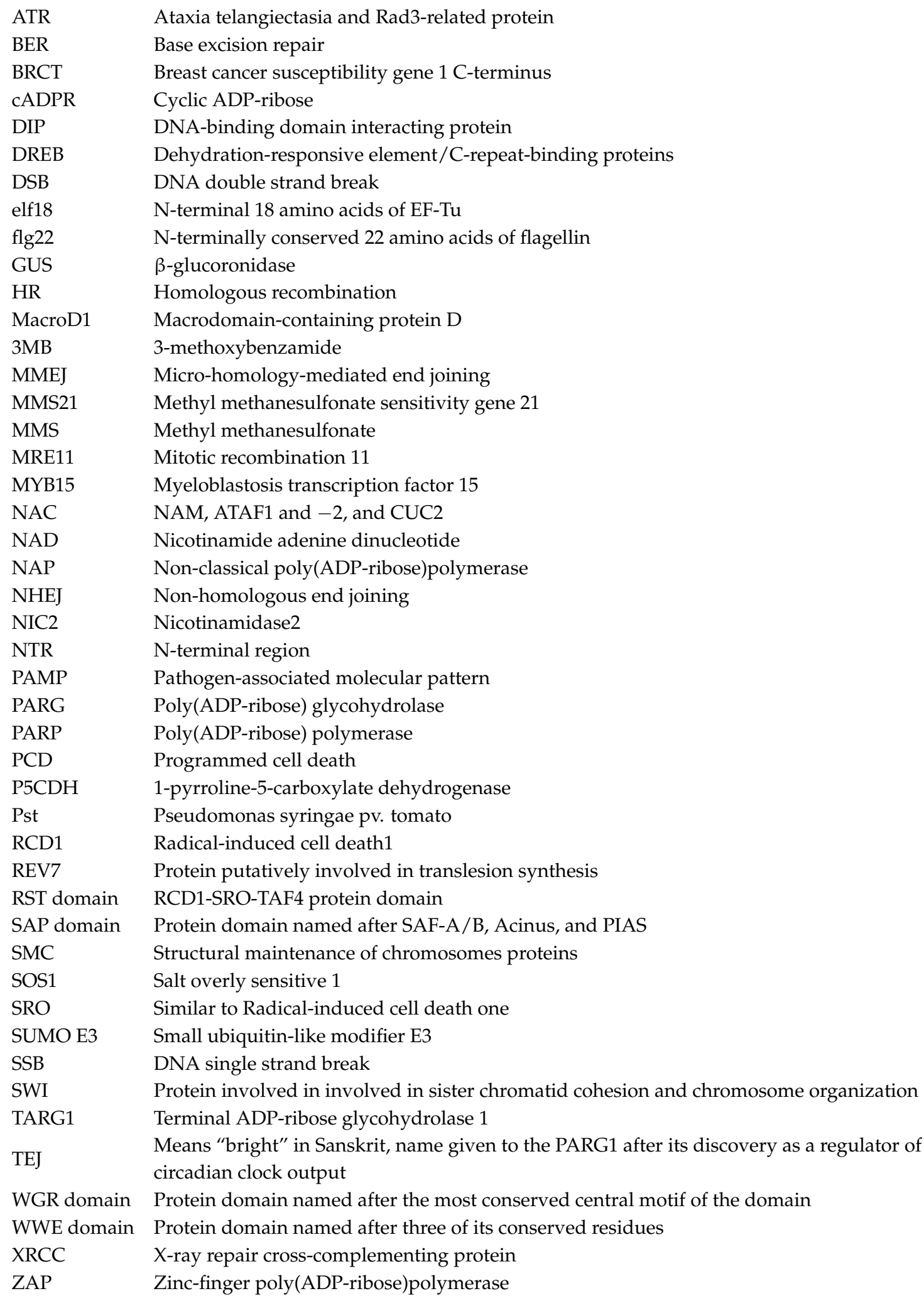

\section{References}

1. Hayashi, K.; Tanaka, M.; Shimada, T.; Miwa, M.; Sugimura, T. Size and shape of poly(ADP-ribose): Examination by gel filtration, gel electrophoresis and electron microscopy. Biochem. Biophys. Res. Commun. 1983, 112, 102-107. [CrossRef] 
2. Kiehlbauch, C.C.; Aboulela, N.; Jacobson, E.L.; Ringer, D.P.; Jacobson, M.K. High-resolution fractionation and characterization of ADP-ribose polymers. Anal. Biochem. 1993, 208, 26-34. [CrossRef] [PubMed]

3. D'Amours, D.; Desnoyers, S.; D'Silva, I.; Poirier, G.G. Poly(ADP-ribosyl)ation reactions in the regulation of nuclear functions. Biochem. J. 1999, 342, 249-268. [CrossRef]

4. Gibson, B.A.; Kraus, W.L. New insights into the molecular and cellular functions of poly(ADP-ribose) and PARPs. Nat. Rev. Mol. Cell Biol. 2012, 13, 411-424. [CrossRef]

5. Brady, P.N.; Goel, A.; Johnson, M.A. Poly(ADP-ribose) polymerases in host-pathogen interactions, inflammation, and immunity. Microbiol. Mol. Biol. Rev. 2019, 83, e00038-18. [CrossRef] [PubMed]

6. Alvarez-Gonzalez, R.; Mendoza-Alvarez, H. Dissection of ADP-ribose polymer synthesis into individual steps of initiation, elongation, and branching. Biochimie 1995, 77, 403-407. [CrossRef]

7. Gakière, B.; Hao, J.; de Bont, L.; Pétriacq, P.; Nunes-Nesi, A.; Fernie, A.R. NAD ${ }^{+}$biosynthesis and signaling in plants. Crit. Rev. Plant Sci. 2018, 37, 259-307. [CrossRef]

8. Gupte, R.; Liu, Z.Y.; Kraus, W.L. PARPs and ADP-ribosylation: Recent advances linking molecular functions to biological outcomes. Genes Dev. 2017, 31, 101-126. [CrossRef]

9. Schuhwerk, H.; Atteya, R.; Siniuk, K.; Wang, Z.Q. PARPing for balance in the homeostasis of poly(ADP-ribosyl)ation. Semin. Cell Dev. Biol. 2017, 63, 81-91. [CrossRef]

10. Pleschke, J.M.; Kleczkowska, H.E.; Strohm, M.; Althaus, F.R. Poly(ADP-ribose) binds to specific domains in DNA damage checkpoint proteins. J. Biol. Chem. 2000, 275, 40974-40980. [CrossRef] [PubMed]

11. Mendoza-Alvarez, H.; Alvarez-Gonzalez, R. Regulation of p53 sequence-specific DNA-binding by covalent poly(ADP-ribosyl)ation. J. Biol. Chem. 2001, 276, 36425-36430. [CrossRef]

12. Chang, P.; Jacobson, M.K.; Mitchison, T.J. Poly(ADP-ribose) is required for spindle assembly and structure. Nature 2004, 432, 645-649. [CrossRef] [PubMed]

13. Haince, J.F.; Kozlov, S.; Dawson, V.L.; Dawson, T.M.; Hendzel, M.J.; Lavin, M.F.; Poirier, G.G. Ataxia telangiectasia mutated (ATM) signaling network is modulated by a novel poly(ADP-ribose)-dependent pathway in the early response to DNA-damaging agents. J. Biol. Chem. 2007, 282, 16441-16453. [CrossRef] [PubMed]

14. Aguilar-Quesada, R.; Munoz-Gamez, J.A.; Martin-Oliva, D.; Peralta, A.; Valenzuela, M.T.; Matinez-Romero, R.; Quiles-Perez, R.; Murcia, J.M.D.; de Murcia, G.; de Almodovar, M.R.; et al. Interaction between ATM and PARP-1 in response to DNA damage and sensitization of ATM deficient cells through PARP inhibition. BMC Mol. Biol. 2007, 8, 29. [CrossRef]

15. Kanai, M.; Hanashiro, K.; Kim, S.H.; Hanai, S.; Boulares, A.H.; Miwa, M.; Fukasawa, K. Inhibition of Crm1-p53 interaction and nuclear export of p53 by poly(ADP-ribosyl)ation. Nat. Cell Biol. 2007, 9, 1175-1183. [CrossRef]

16. Kedar, P.S.; Stefanick, D.F.; Horton, J.K.; Wilson, S.H. Interaction between PARP-1 and ATR in mouse fibroblasts is blocked by PARP inhibition. DNA Rep. 2008, 7, 1787-1798. [CrossRef]

17. Ahel, I.; Ahel, D.; Matsusaka, T.; Clark, A.J.; Pines, J.; Boulton, S.J.; West, S.C. Poly(ADP-ribose)-binding zinc finger motifs in DNA repair/checkpoint proteins. Nature 2008, 451, 81-85. [CrossRef]

18. Gagné, J.P.; Isabelle, M.; Lo, K.S.; Bourassa, S.; Hendzel, M.J.; Dawson, V.L.; Dawson, T.M.; Poirier, G.G. Proteome-wide identification of poly(ADP-ribose) binding proteins and poly(ADP-ribose)-associated protein complexes. Nucl. Acid Res. 2008, 36, 6959-6976. [CrossRef]

19. Ahel, D.; Horejsi, Z.; Wiechens, N.; Polo, S.E.; Garcia-Wilson, E.; Ahel, I.; Flynn, H.; Skehel, M.; West, S.C.; Jackson, S.P.; et al. Poly(ADP-ribose)-dependent regulation of DNA repair by the chromatin remodeling enzyme ALC1. Science 2009, 325, 1240-1243. [CrossRef]

20. Wang, Y.F.; Dawson, V.L.; Dawson, T.M. Poly(ADP-ribose) signals to mitochondrial AIF: A key event in parthanatos. Exp. Neurol. 2009, 218, 193-202. [CrossRef] [PubMed]

21. Kang, H.C.; Lee, Y.I.; Shin, J.H.; Andrabi, S.A.; Chi, Z.K.; Gagne, J.P.; Lee, Y.J.; Ko, H.S.; Lee, B.D.; Poirier, G.G.; et al. Iduna is a poly(ADP-ribose) (PAR)-dependent E3 ubiquitin ligase that regulates DNA damage. Proc. Natl. Acad. Sci. USA 2011, 108, 14103-14108. [CrossRef]

22. Min, W.; Bruhn, C.; Grigaravicius, P.; Zhou, Z.W.; Li, F.; Kruger, A.; Siddeek, B.; Greulich, K.O.; Popp, O.; Meisezahl, C.; et al. Poly(ADP-ribose) binding to Chk1 at stalled replication forks is required for S-phase checkpoint activation. Nat. Commun. 2013, 4, 2993. [CrossRef] [PubMed]

23. Liu, C.; Wu, J.X.; Paudyal, S.C.; You, Z.S.; Yu, X.C. CHFR is important for the first wave of ubiquitination at DNA damage sites. Nucl. Acid Res. 2013, 41, 1698-1710. [CrossRef] [PubMed] 
24. Aredia, F.; Scovassi, A.I. Poly(ADP-ribose): A signaling molecule in different paradigms of cell death. Biochem. Pharmacol. 2014, 92, 157-163. [CrossRef] [PubMed]

25. Stadler, J.; Richly, H. Regulation of DNA repair mechanisms: How the chromatin environment regulates the DNA damage response. Int. J. Mol. Sci. 2017, 18, 1715. [CrossRef]

26. Tao, Z.; Gao, P.; Liu, H.-W. Studies of the expression of human poly(ADP-ribose) polymerase-1 in Saccharomyces cerevisiae and identification of PARP-1 substrates by yeast proteome microarray screening. Biochemistry 2009, 48, 11745-11754. [CrossRef] [PubMed]

27. Crawford, K.; Bonfiglio, J.J.; Mikoc, A.; Matic, I.; Ahel, I. Specificity of reversible ADP-ribosylation and regulation of cellular processes. Crit. Rev. Biochem. Mol. Biol. 2018, 53, 64-82. [CrossRef]

28. Cohen, M.S.; Chang, P. Insights into the biogenesis, function, and regulation of ADP-ribosylation. Nat. Chem. Biol. 2018, 14, 236-243. [CrossRef]

29. Bonfiglio, J.J.; Fontana, P.; Zhang, Q.; Colby, T.; Gibbs-Seymour, I.; Atanassov, I.; Bartlett, E.; Zaja, R.; Ahel, I.; Matic, I. Serine ADP-ribosylation depends on HPF1. Mol. Cell 2017, 65, 932-940. [CrossRef]

30. Slade, D.; Dunstan, M.S.; Barkauskaite, E.; Weston, R.; Lafite, P.; Dixon, N.; Ahel, M.; Leys, D.; Ahel, I. The structure and catalytic mechanism of a poly(ADP-ribose) glycohydrolase. Nature 2011, 477, 616-620. [CrossRef]

31. Perina, D.; Mikoc, A.; Ahel, J.; Cetkovic, H.T.; Zaja, R.; Ahel, I. Distribution of protein poly(ADP-ribosyl)ation systems across all domains of life. DNA Rep. 2014, 23, 4-16. [CrossRef] [PubMed]

32. Amé, J.C.; Spenlehauer, C.; de Murcia, G. The PARP superfamily. Bioessays 2004, 26, 882-893. [CrossRef]

33. Otto, H.; Reche, P.A.; Bazan, F.; Dittmar, K.; Haag, F.; Koch-Nolte, F. In silico characterization of the family of PARP-like poly(ADP-ribosyl) transferases (pARTs). BMC Genom. 2005, 6, 139. [CrossRef] [PubMed]

34. Hottiger, M.O.; Hassa, P.O.; Luscher, B.; Schuler, H.; Koch-Nolte, F. Toward a unified nomenclature for mammalian ADP-ribosyltransferases. Trends Biochem. Sci. 2010, 35, 208-219. [CrossRef]

35. Vyas, S.; Chesarone-Cataldo, M.; Todorova, T.; Huang, Y.H.; Chang, P. A systematic analysis of the PARP protein family identifies new functions critical for cell physiology. Nat. Commun. 2013, 4, 2240. [CrossRef]

36. Rolli, V.; O'Farrell, M.; Menissier de Murcia, J.; de Murcia, G. Random mutagenesis of the poly(ADP-ribose) polymerase catalytic domain reveals amino acids involved in polymer branching. Biochemistry 1997, 36, 12147-12154. [CrossRef]

37. Vyas, S.; Matic, I.; Uchima, L.; Rood, J.; Zaja, R.; Hay, R.T.; Ahel, I.; Chang, P. Family-wide analysis of poly(ADP-ribose) polymerase activity. Nat. Commun. 2014, 5, 4426. [CrossRef]

38. Kraus, W.L.; Lis, J.T. PARP goes transcription. Cell 2003, 113, 677-683. [CrossRef]

39. Rouleau, M.; Patel, A.; Hendzel, M.J.; Kaufmann, S.H.; Poirier, G.G. PARP inhibition: PARP1 and beyond. Nat. Rev. Cancer 2010, 10, 293-301. [CrossRef]

40. Ikejima, M.; Noguchi, S.; Yamashita, R.; Ogura, T.; Sugimura, T.; Gill, D.M.; Miwa, M. The zinc fingers of human poly(ADP-ribose) polymerase are differentially required for the recognition of DNA breaks and nicks and the consequent enzyme activation. Other structures recognize intact DNA. J. Biol. Chem. 1990, 265, 21907-21913. [PubMed]

41. Gradwohl, G.; Demurcia, J.M.; Molinete, M.; Simonin, F.; Koken, M.; Hoeijmakers, J.H.J.; Demurcia, G. The 2nd zinc-finger domain of poly(ADP-ribose) polymerase determines specificity for single-stranded breaks in DNA. Proc. Natl. Acad. Sci. USA 1990, 87, 2990-2994. [CrossRef]

42. Langelier, M.F.; Planck, J.L.; Roy, S.; Pascal, J.M. Structural basis for DNA damage-dependent poly(ADP-ribosyl)ation by human PARP-1. Science 2012, 336, 728-732. [CrossRef]

43. Langelier, M.F.; Ruhl, D.D.; Planck, J.L.; Kraus, W.L.; Pascal, J.M. The Zn3 domain of human poly(ADP-ribose) polymerase-1 (PARP-1) functions in both DNA-dependent poly(ADP-ribose) synthesis activity and chromatin compaction. J. Biol. Chem. 2010, 285, 18877-18887. [CrossRef] [PubMed]

44. Dawicki-McKenna, J.M.; Langelier, M.F.; DeNizio, J.E.; Riccio, A.A.; Cao, C.D.; Karch, K.R.; McCauley, M.; Steffen, J.D.; Black, B.E.; Pascal, J.M. PARP-1 activation requires local unfolding of an autoinhibitory domain. Mol. Cell 2015, 60, 755-768. [CrossRef] [PubMed]

45. Eustermann, S.; Wu, W.F.; Langelier, M.F.; Yang, J.C.; Easton, L.E.; Riccio, A.A.; Pascal, J.M.; Neuhaus, D. Structural basis of detection and signaling of DNA single-strand breaks by human PARP-1. Mol. Cell 2015, 60, 742-754. [CrossRef]

46. Steffen, J.D.; McCauley, M.M.; Pascal, J.M. Fluorescent sensors of PARP-1 structural dynamics and allosteric regulation in response to DNA damage. Nucl. Acid Res. 2016, 44, 9771-9783. [CrossRef] [PubMed] 
47. Rissel, D.; Heym, P.P.; Thor, K.; Brandt, W.; Wessjohann, L.A.; Peiter, E. No silver bullet - Canonical poly(ADP-ribose) polymerases (PARPs) are no universal factors of abiotic and biotic stress resistance of Arabidopsis thaliana. Front. Plant Sci. 2017, 8, 59. [CrossRef] [PubMed]

48. Masson, M.; Niedergang, C.; Schreiber, V.; Muller, S.; Menissier-de Murcia, J.; de Murcia, G. XRCC1 is specifically associated with poly(ADP-ribose) polymerase and negatively regulates its activity following DNA damage. Mol. Cell. Biol. 1998, 18, 3563-3571. [CrossRef] [PubMed]

49. Okano, S.; Lan, L.; Caldecott, K.W.; Mori, T.; Yasui, R. Spatial and temporal cellular responses to single-strand breaks in human cells. Mol. Cell. Biol. 2003, 23, 3974-3981. [CrossRef]

50. El-Khamisy, S.F.; Masutani, M.; Suzuki, H.; Caldecott, K.W. A requirement for PARP-1 for the assembly or stability of XRCC1 nuclear foci at sites of oxidative DNA damage. Nucl. Acid Res. 2003, 31, 5526-5533. [CrossRef]

51. Haince, J.F.; McDonald, D.; Rodrigue, A.; Dery, U.; Masson, J.Y.; Hendzel, M.J.; Poirier, G.G. PARP1-dependent kinetics of recruitment of MRE11 and NBS1 proteins to multiple DNA damage sites. J. Biol. Chem. 2008, 283, 1197-1208. [CrossRef]

52. Hochegger, H.; Dejsuphong, D.; Fukushima, T.; Morrison, C.; Sonoda, E.; Schreiber, V.; Zhao, G.Y.; Saberi, A.; Masutani, M.; Adachi, N.; et al. PARP-1 protects homologous recombination from interference by $\mathrm{Ku}$ and ligase IV in vertebrate cells. EMBO J. 2006, 25, 1305-1314. [CrossRef]

53. Beck, C.; Robert, I.; Reina-San-Martin, B.; Schreiber, V.; Dantzer, F. Poly(ADP-ribose) polymerases in double-strand break repair: Focus on PARP1, PARP2 and PARP3. Exp. Cell Res. 2014, 329, 18-25. [CrossRef]

54. Galande, S.; Kohwi-Shigematso, T. Poly(ADP-ribose) polymerase and Ku autoantigen form a complex and synergistically bind to matrix attachment sequences. J. Biol. Chem. 1999, 274, 20521-20528. [CrossRef]

55. Wang, M.L.; Wu, W.Z.; Wu, W.Q.; Rosidi, B.; Zhang, L.H.; Wang, H.C.; Iliakis, G. PARP-1 and Ku compete for repair of DNA double strand breaks by distinct NHEJ pathways. Nucl. Acid Res. 2006, 34, 6170-6182. [CrossRef]

56. Frizzell, K.M.; Gamble, M.J.; Berrocal, J.G.; Zhang, T.; Krishnakumar, R.; Cen, Y.; Sauve, A.A.; Kraus, W.L. Global analysis of transcriptional regulation by poly(ADP-ribose) polymerase-1 and poly(ADP-ribose) glycohydrolase in MCF-7 human breast cancer cells. J. Biol. Chem. 2009, 284, 33926-33938. [CrossRef]

57. Amé, J.C.; Rolli, V.; Schreiber, V.; Niedergang, C.; Apiou, F.; Decker, P.; Muller, S.; Hoger, T.; Murcia, J.M.D.; de Murcia, G. PARP-2, a novel mammalian DNA damage-dependent poly(ADP-ribose) polymerase. J. Biol. Chem. 1999, 274, 17860-17868. [CrossRef] [PubMed]

58. Kutuzov, M.M.; Khodyreva, S.N.; Schreiber, V.; Lavrik, O.I. Role of PARP2 in DNA repair. Mol. Biol. 2014, 48, 485-495. [CrossRef]

59. Riccio, A.A.; Cingolani, G.; Pascal, J.M. PARP-2 domain requirements for DNA damage-dependent activation and localization to sites of DNA damage. Nucl. Acid Res. 2016, 44, 1691-1702. [CrossRef]

60. Schreiber, V.; Ame, J.C.; Dolle, P.; Schultz, I.; Rinaldi, B.; Fraulob, V.; Menissier-de Murcia, J.; de Murcia, G. Poly(ADP-ribose) polymerase-2 (PARP-2) is required for efficient base excision DNA repair in association with PARP-1 and XRCC1. J. Biol. Chem. 2002, 277, 23028-23036. [CrossRef] [PubMed]

61. Isabelle, M.; Moreel, X.; Gagne, J.P.; Rouleau, M.; Ethier, C.; Gagne, P.; Hendzel, M.J.; Poirier, G.G. Investigation of PARP-1, PARP-2, and PARG interactomes by affinity-purification mass spectrometry. Proteome Sci. 2010, 8, 22. [CrossRef]

62. Hanzlikova, H.; Gittens, W.; Krejcikova, K.; Zeng, Z.H.; Caldecott, K.W. Overlapping roles for PARP1 and PARP2 in the recruitment of endogenous XRCC1 and PNKP into oxidized chromatin. Nucl. Acid Res. 2017, 45, 2546-2557. [CrossRef]

63. De Murcia, J.M.N.; Ricoul, M.; Tartier, L.; Niedergang, C.; Huber, A.; Dantzer, F.; Schreiber, V.; Ame, J.C.; Dierich, A.; LeMeur, M.; et al. Functional interaction between PARP-1 and PARP-2 in chromosome stability and embryonic development in mouse. EMBO J. 2003, 22, 2255-2263. [CrossRef]

64. Bryant, H.E.; Petermann, E.; Schultz, N.; Jemth, A.S.; Loseva, O.; Issaeva, N.; Johansson, F.; Fernandez, S.; McGlynn, P.; Helleday, T. PARP is activated at stalled forks to mediate Mre11-dependent replication restart and recombination. EMBO J. 2009, 28, 2601-2615. [CrossRef]

65. Fouquin, A.; Guirouilh-Barbat, J.; Lopez, B.; Hall, J.; Amor-Gueret, M.; Pennaneach, V. PARP2 controls double-strand break repair pathway choice by limiting 53BP1 accumulation at DNA damage sites and promoting end-resection. Nucl. Acid Res. 2017, 45, 12325-12339. [CrossRef] [PubMed] 
66. Boehler, C.; Dantzer, F. PARP-3, a DNA-dependent PARP with emerging roles in double-strand break repair and mitotic progression. Cell Cycle 2011, 10, 1023-1024. [CrossRef]

67. Rulten, S.L.; Fisher, A.E.O.; Robert, I.; Zuma, M.C.; Rouleau, M.; Ju, L.M.; Poirier, G.; Reina-San-Martin, B.; Caldecott, K.W. PARP-3 and APLF function together to accelerate nonhomologous end-joining. Mol. Cell 2011, 41, 33-45. [CrossRef]

68. Rouleau, M.; McDonald, D.; Gagné, P.; Ouellet, M.-E.; Droit, A.; Hunter, J.M.; Dutertre, S.; Prigent, C.; Hendzel, M.J.; Poirier, G.G. PARP-3 associates with polycomb group bodies and with components of the DNA damage repair machinery. J. Cell. Biochem. 2007, 100, 385-401. [CrossRef]

69. Loseva, O.; Jemth, A.S.; Bryant, H.E.; Schuler, H.; Lehtio, L.; Karlberg, T.; Helleday, T. PARP-3 is a mono-ADP-ribosylase that activates PARP-1 in the absence of DNA. J. Biol. Chem. 2010, 285, 8054-8060. [CrossRef] [PubMed]

70. Lin, W.S.; Ame, J.C.; AboulEla, N.; Jacobson, E.L.; Jacobson, M.K. Isolation and characterization of the cDNA encoding bovine poly(ADP-ribose) glycohydrolase. J. Biol. Chem. 1997, 272, 11895-11901. [CrossRef] [PubMed]

71. Barkauskaite, E.; Brassington, A.; Tan, E.S.; Warwicker, J.; Dunstan, M.S.; Banos, B.; Lafite, P.; Ahel, M.; Mitchison, T.J.; Ahel, I.; et al. Visualization of poly(ADP-ribose) bound to PARG reveals inherent balance between exo- and endo-glycohydrolase activities. Nat. Commun. 2013, 4, 2164. [CrossRef] [PubMed]

72. Thomassin, H.; Menard, L.; Hengartner, C.; Kirkland, J.B.; Poirier, G.G. Poly(ADP-ribosyl)ation of chromatin in an in vitro poly(ADP-ribose)-turnover system. Biochim. Biophys. Act. 1992, 1137, 171-181. [CrossRef]

73. Brochu, G.; Duchaine, C.; Thibeault, L.; Lagueux, J.; Shah, G.M.; Poirier, G.G. Mode of action of poly(ADP-ribose) glycohydrolase. Biochim. Biophys. Act. 1994, 1219, 342-350. [CrossRef]

74. Meyer-Ficca, M.L.; Meyer, R.G.; Coyle, D.L.; Jacobson, E.L.; Jacobson, M.K. Human poly(ADP-ribose) glycohydrolase is expressed in alternative splice variants yielding isoforms that localize to different cell compartments. Exp. Cell Res. 2004, 297, 521-532. [CrossRef] [PubMed]

75. Meyer, R.G.; Meyer-Ficca, M.L.; Whatcott, C.J.; Jacobson, E.L.; Jacobson, M.K. Two small enzyme isoforms mediate mammalian mitochondrial poly(ADP-ribose) glycohydrolase (PARG) activity. Exp. Cell Res. 2007, 313, 2920-2936. [CrossRef] [PubMed]

76. Koh, D.W.; Lawler, A.M.; Poitras, M.F.; Sasaki, M.; Wattler, S.; Nehls, M.C.; Stoger, T.; Poirier, G.G.; Dawson, V.L.; Dawson, T.M. Failure to degrade poly(ADP-ribose) causes increased sensitivity to cytotoxicity and early embryonic lethality. Proc. Natl. Acad. Sci. USA 2004, 101, 17699-17704. [CrossRef] [PubMed]

77. Hanai, S.; Kanai, M.; Ohashi, S.; Okamoto, K.; Yamada, M.; Takahashi, H.; Miwa, M. Loss of poly(ADP-ribose) glycohydrolase causes progressive neurodegeneration in Drosophila melanogaster. Proc. Natl. Acad. Sci. USA 2004, 101, 82-86. [CrossRef]

78. Oka, S.; Kato, J.; Moss, J. Identification and characterization of a mammalian 39-kDa poly(ADP-ribose) glycohydrolase. FASEB J. 2006, 20, A45. [CrossRef]

79. Niere, M.; Kernstock, S.; Koch-Nolte, F.; Ziegler, M. Functional localization of two poly(ADP-ribose)-degrading enzymes to the mitochondrial matrix. Mol. Cell. Biol. 2008, 28, 814-824. [CrossRef] [PubMed]

80. Jankevicius, G.; Hassler, M.; Golia, B.; Rybin, V.; Zacharias, M.; Timinszky, G.; Ladurner, A.G. A family of macrodomain proteins reverses cellular mono-ADP-ribosylation. Nat. Struct. Mol. Biol. 2013, 20, 508-514. [CrossRef]

81. Rosenthal, F.; Feijs, K.L.H.; Frugier, E.; Bonalli, M.; Forst, A.H.; Imhof, R.; Winkler, H.C.; Fischer, D.; Caflisch, A.; Hassa, P.O.; et al. Macrodomain-containing proteins are new mono-ADP-ribosylhydrolases. Nat. Struct. Mol. Biol. 2013, 20, 502-507. [CrossRef] [PubMed]

82. Sharifi, R.; Morra, R.; Appel, C.D.; Tallis, M.; Chioza, B.; Jankevicius, G.; Simpson, M.A.; Matic, I.; Ozkan, E.; Golia, B.; et al. Deficiency of terminal ADP-ribose protein glycohydrolase TARG1/C6orf130 in neurodegenerative disease. EMBO J. 2013, 32, 1225-1237. [CrossRef] [PubMed]

83. Payne, J.F.; Bal, A.K. Cytological detection of poly (ADP-ribose) polymerase. Exp. Cell Res. 1976, 99, 428-432. [CrossRef]

84. Whitby, A.J.; Whish, W.J. Poly(adenoise diphosphate ribose) in wheat [proceedings]. Biochem. Soc. Transact. 1977, 5, 948-949. [CrossRef]

85. Whitby, A.J.; Whish, W.J. Poly(adenosine diphosphate ribose) glycohydrolase in germinating wheat embryos [proceedings]. Biochem. Soc. Transact. 1978, 6, 619-620. [CrossRef] 
86. Whitby, A.J.; Stone, P.R.; Whish, W.J.D. Effect of polyamines and $\mathrm{Mg}^{++}$on poly(ADP-ribose) synthesis and ADP-ribosylation of histones in wheat. Biochem. Biophys. Res. Commun. 1979, 90, 1295-1304. [CrossRef]

87. Willmitzer, L. Demonstration of in vitro covalent modification of chromosomal-proteins by poly(ADP) ribosylation in plant nuclei. FEBS Lett. 1979, 108, 13-16. [CrossRef]

88. Chen, Y.-M.; Shall, S.; O’Farrell, M. Poly(ADP-ribose) polymerase in plant nuclei. Eur. J. Biochem. 1994, 224, 135-142. [CrossRef]

89. Lepiniec, L.; Babiychuk, E.; Kushnir, S.; Van Montagu, M.; Inzé, D. Characterization of an Arabidopsis thaliana cDNA homologue to animal poly(ADP-ribose) polymerase. FEBS Lett. 1995, 364, 103-108. [CrossRef] [PubMed]

90. Aravind, L.; Koonin, E.V. SAP-A putative DNA-binding motif involved in chromosomal organization. Trends Biochem. Sci. 2000, 25, 112-114. [CrossRef]

91. Babiychuk, E.; Cottrill, P.B.; Storozhenko, S.; Fuangthong, M.; Chen, Y.; O'Farrell, M.K.; Van Montagu, M.; Inzé, D.; Kushnir, S. Higher plants possess two structurally different poly(ADP-ribose) polymerases. Plant J. 1998, 15, 635-645. [CrossRef] [PubMed]

92. Song, J.; Keppler, B.D.; Wise, R.R.; Bent, A.F. PARP2 is the predominant poly(ADP-ribose) polymerase in Arabidopsis DNA damage and immune responses. PLOS Genet. 2015, 11, e1005200. [CrossRef] [PubMed]

93. Pham, P.A.; Wahl, V.; Tohge, T.; de Souza, L.R.; Zhang, Y.; Do, P.T.; Olas, J.J.; Stitt, M.; Araújo, W.L.; Fernie, A.R. Analysis of knockout mutants reveals non-redundant functions of poly(ADP-ribose)polymerase isoforms in Arabidopsis. Plant Mol. Biol. 2015, 89, 319-338. [CrossRef]

94. Chen, C.; De Masi, R.; Lintermann, R.; Wirthmueller, L. Nuclear import of Arabidopsis poly(ADP-ribose) polymerase 2 is mediated by importin- $\alpha$ and a nuclear localization sequence located between the predicted SAP domains. Front. Plant Sci. 2018, 9, 1581. [CrossRef] [PubMed]

95. Doucet-Chabeaud, G.; Godon, C.; Brutesco, C.; de Murcia, G.; Kazmaier, M. Ionising radiation induces the expression of PARP-1 and PARP-2 genes in Arabidopsis. Mol. Genet. Genom. 2001, 265, 954-963.

96. Rissel, D.; Heym, P.P.; Peiter, E. A yeast growth assay to characterize plant poly(ADP-ribose) polymerase (PARP) proteins and inhibitors. Anal. Biochem. 2017, 527, 20-23. [CrossRef]

97. Boltz, K.A.; Jasti, M.; Townley, J.M.; Shippen, D.E. Analysis of poly(ADP-ribose) polymerases in Arabidopsis telomere biology. PLoS ONE 2014, 9, e88872. [CrossRef]

98. Briggs, A.G.; Bent, A.F. Poly(ADP-ribosyl)ation in plants. Trends Plant Sci. 2011, 16, 372-380. [CrossRef]

99. De Block, M.; Verduyn, C.; De Brouwer, D.; Cornelissen, M. Poly(ADP-ribose) polymerase in plants affects energy homeostasis, cell death and stress tolerance. Plant J. 2005, 41, 95-106. [CrossRef]

100. Jia, Q.; den Dulk-Ras, A.; Shen, H.; Hooykaas, P.J.J.; de Pater, S. Poly(ADP-ribose)polymerases are involved in microhomology mediated back-up non-homologous end joining in Arabidopsis thaliana. Plant Mol. Biol. 2013, 82, 339-351. [CrossRef]

101. Feng, B.; Liu, C.; de Oliveira, M.V.V.; Intorne, A.C.; Li, B.; Babilonia, K.; de Souza Filho, G.A.; Shan, L.; $\mathrm{He}$, P. Protein poly(ADP-ribosyl)ation regulates Arabidopsis immune gene expression and defense responses. PLOS Genet. 2015, 11, e1004936. [CrossRef] [PubMed]

102. Keppler, B.D.; Song, J.Q.; Nyman, J.; Voigt, C.A.; Bent, A.F. 3-aminobenzamide blocks MAMP-induced callose deposition independently of its poly(ADPribosyl)ation inhibiting activity. Front. Plant Sci. 2018, 9, 1907. [CrossRef]

103. Lamb, R.S.; Citarelli, M.; Teotia, S. Functions of the poly(ADP-ribose) polymerase superfamily in plants. Cell. Mol. Life Sci. 2012, 69, 175-189. [CrossRef]

104. Ogawa, T.; Ishikawa, K.; Harada, K.; Fukusaki, E.; Yoshimura, K.; Shigeoka, S. Overexpression of an ADP-ribose pyrophosphatase, AtNUDX2, confers enhanced tolerance to oxidative stress in Arabidopsis plants. Plant J. 2009, 57, 289-301. [CrossRef]

105. Pellny, T.K.; Locato, V.; Vivancos, P.D.; Markovic, J.; De Gara, L.; Pallardo, F.V.; Foyer, C.H. Pyridine nucleotide cycling and control of intracellular redox state in relation to poly (ADP-ribose) polymerase activity and nuclear localization of glutathione during exponential growth of Arabidopsis cells in culture. Mol. Plant 2009, 2, 442-456. [CrossRef]

106. Schulz, P.; Neukermans, J.; Van der Kelen, K.; Mühlenbock, P.; Van Breusegem, F.; Noctor, G.; Teige, M.; Metzlaff, M.; Hannah, M.A. Chemical PARP inhibition enhances growth of Arabidopsis and reduces anthocyanin accumulation and the activation of stress protective mechanisms. PLoS ONE 2012, 7, e37284. [CrossRef] 
107. Vanderauwera, S.; De Block, M.; Van de Steene, N.; Van de Cotte, B.; Metzlaff, M.; Van Breusegem, F. Silencing of poly(ADP-ribose) polymerase in plants alters abiotic stress signal transduction. Proc. Natl. Acad. Sci. USA 2007, 104, 15150-15155. [CrossRef] [PubMed]

108. Zhang, H.; Gu, Z.; Wu, Q.; Yang, L.; Liu, C.; Ma, H.; Xia, Y.; Ge, X. Arabidopsis PARG1 is the key factor promoting cell survival among the enzymes regulating post-translational poly(ADP-ribosyl)ation. Sci. Rep. 2015, 5, 15892. [CrossRef] [PubMed]

109. Hunt, L.; Lerner, F.; Ziegler, M. NAD-New roles in signalling and gene regulation in plants. New Phytol. 2004, 163, 31-44. [CrossRef]

110. Rissel, D.; Losch, J.; Peiter, E. The nuclear protein Poly(ADP-ribose) polymerase 3 (AtPARP3) is required for seed storability in Arabidopsis thaliana. Plant Biol. 2014, 16, 1058-1064. [CrossRef] [PubMed]

111. Perkins, E.; Sun, D.; Nguyen, A.; Tulac, S.; Francesco, M.; Tavana, H.; Nguyen, H.; Tugendreich, S.; Barthmaier, P.; Couto, J.; et al. Novel inhibitors of poly(ADP-ribose) polymerase/PARP1 and PARP2 identified using a cell-based screen in yeast. Cancer Res. 2001, 61, 4175-4183. [PubMed]

112. Panda, S.; Poirier, G.G.; Kay, S.A. tej defines a role for poly(ADP-ribosyl)ation in establishing period length of the Arabidopsis circadian oscillator. Dev. Cell 2002, 3, 51-61. [CrossRef]

113. Yuan, D.; Lai, J.; Xu, P.; Zhang, S.; Zhang, J.; Li, C.; Wang, Y.; Du, J.; Liu, Y.; Yang, C. AtMMS21 regulates DNA damage response and homologous recombination repair in Arabidopsis. DNA Rep. 2014, 21, 140-147. [CrossRef] [PubMed]

114. Stolarek, M.; Gruszka, D.; Braszewska-Zalewska, A.; Maluszynski, M. Alleles of newly identified barley gene HvPARP3 exhibit changes in efficiency of DNA repair. DNA Rep. 2015, 28, 116-130. [CrossRef] [PubMed]

115. Arena, C.; De Micco, V.; De Maio, A. Growth alteration and leaf biochemical responses in Phaseolus vulgaris exposed to different doses of ionising radiation. Plant Biol. 2014, 16, 194-202. [CrossRef]

116. Liu, C.; Wu, Q.; Liu, W.; Gu, Z.; Wang, W.; Xu, P.; Ma, H.; Ge, X. Poly(ADP-ribose) polymerases regulate cell division and development in Arabidopsis roots. J. Integr. Plant Biol. 2017, 59, 459-474. [CrossRef]

117. Klemm, T.; Mannuss, A.; Kobbe, D.; Knoll, A.; Trapp, O.; Dorn, A.; Puchta, H. The DNA translocase RAD5A acts independently of the other main DNA repair pathways, and requires both its ATPase and RING domain for activity in Arabidopsis thaliana. Plant J. 2017, 91, 725-740. [CrossRef]

118. Song, J.Q.; Bent, A.F. Microbial pathogens trigger host DNA double-strand breaks whose abundance is reduced by plant defense responses. PLOS Path. 2014, 10, e1004030. [CrossRef]

119. De Schutter, K.; Joubes, J.; Cools, T.; Verkest, A.; Corellou, F.; Babiychuk, E.; Van Der Schueren, E.; Beeckman, T.; Kushnir, S.; Inze, D.; et al. Arabidopsis WEE1 kinase controls cell cycle arrest in response to activation of the DNA integrity checkpoint. Plant Cell 2007, 19, 211-225. [CrossRef]

120. Tuteja, N.; Ahmad, P.; Panda, B.B.; Tuteja, R. Genotoxic stress in plants: Shedding light on DNA damage, repair and DNA repair helicases. Mut. Res. Rev. Mut. Res. 2009, 681, 134-149. [CrossRef] [PubMed]

121. Puchta, H.; Swoboda, P.; Hohn, B. Induction of intrachromosomal homologous recombination in whole plants. Plant J. 1995, 7, 203-210. [CrossRef]

122. Ishikawa, K.; Ogawa, T.; Hirosue, E.; Nakayama, Y.; Harada, K.; Fukusaki, E.; Yoshimura, K.; Shigeoka, S. Modulation of the poly(ADP-ribosyl)ation reaction via the Arabidopsis ADP-Ribose/NADH pyrophosphohydrolase, AtNUDX7, is involved in the response to oxidative stress. Plant Physiol. 2009, 151, 741-754. [CrossRef]

123. Shen, H.; Strunks, G.D.; Klemann, B.J.P.M.; Hooykaas, P.J.J.; de Pater, S. CRISPR/Cas9-induced double-strand break repair in Arabidopsis nonhomologous end-joining mutants. G3 Gen. Genom. Genet. 2017, 7, 193-202. [CrossRef]

124. Spampinato, C.P. Protecting DNA from errors and damage: An overview of DNA repair mechanisms in plants compared to mammals. Cell. Mol. Life Sci. 2017, 74, 1693-1709. [CrossRef]

125. Howell, K.A.; Narsai, R.; Carroll, A.; Ivanova, A.; Lohse, M.; Usadel, B.; Millar, A.H.; Whelan, J. Mapping metabolic and transcript temporal switches during germination in rice highlights specific transcription factors and the role of RNA instability in the germination process. Plant Physiol. 2009, 149, 961-980. [CrossRef]

126. Hunt, L.; Holdsworth, M.J.; Gray, J.E. Nicotinamidase activity is important for germination. Plant J. 2007, 51, 341-351. [CrossRef] [PubMed]

127. Hunt, L.; Gray, J.E. The relationship between pyridine nucleotides and seed dormancy. New Phytol. 2009, 181, 62-70. [CrossRef] [PubMed] 
128. Sano, N.; Rajjou, L.; North, H.M.; Debeaujon, I.; Marion-Poll, A.; Seo, M. Staying alive: Molecular aspects of seed longevity. Plant Cell Physiol. 2016, 57, 660-674. [CrossRef]

129. Li, W.; Zhang, F.; Chang, Y.; Zhao, T.; Schranz, M.E.; Wang, G. Nicotinate O-glucosylation is an evolutionarily metabolic trait important for seed germination under stress conditions in Arabidopsis thaliana. Plant Cell 2015, 27, 1907-1924. [CrossRef] [PubMed]

130. Adams-Phillips, L.; Briggs, A.G.; Bent, A.F. Disruption of poly(ADP-ribosyl)ation mechanisms alters responses of Arabidopsis to biotic stress. Plant Physiol. 2010, 152, 267-280. [CrossRef]

131. Briggs, A.G.; Adams-Phillips, L.C.; Keppler, B.D.; Zebell, S.G.; Arend, K.C.; Apfelbaum, A.A.; Smith, J.A.; Bent, A.F. A transcriptomics approach uncovers novel roles for poly(ADP-ribosyl) ation in the basal defense response in Arabidopsis thaliana. PLoS ONE 2017, 12, e0190268. [CrossRef] [PubMed]

132. Babiychuk, E.; Van Montagu, M.; Kushnir, S. N-terminal domains of plant poly(ADP-ribose) polymerases define their association with mitotic chromosomes. Plant J. 2001, 28, 245-255. [CrossRef] [PubMed]

133. Storozhenko, S.; Inzé, D.; Van Montagu, M.; Kushnir, S. Arabidopsis coactivator ALY-like proteins, DIP1 and DIP2, interact physically with the DNA-binding domain of the Zn-finger poly(ADP-ribose) polymerase. J. Exp. Bot. 2001, 52, 1375-1380. [CrossRef] [PubMed]

134. Cifuentes-Rojas, C.; Nelson, A.D.L.; Boltz, K.A.; Kannan, K.; She, X.T.; Shippen, D.E. An alternative telomerase RNA in Arabidopsis modulates enzyme activity in response to DNA damage. Genes Dev. 2012, 26, 2512-2523. [CrossRef] [PubMed]

135. Amor, Y.; Babiychuk, E.; Inzé, D.; Levine, A. The involvement of poly(ADP-ribose) polymerase in the oxidative stress responses in plants. FEBS Lett. 1998, 440, 1-7. [CrossRef]

136. Tian, R.-H.; Zhang, G.-Y.; Yan, C.-H.; Dai, Y.-R. Involvement of poly(ADP-ribose) polymerase and activation of caspase-3-like protease in heat shock-induced apoptosis in tobacco suspension cells. FEBS Lett. 2000, 474, 11-15. [CrossRef]

137. Vainonen, J.P.; Shapiguzov, A.; Vaattovaara, A.; Kangasjarvi, J. Plant PARPs, PARGs and PARP-like proteins. Curr. Prot. Pept. Sci. 2016, 17, 713-723. [CrossRef]

138. Phillips, R.; Hawkins, S.W. Characteristics of the inhibition of induced tracheary element differentiation by 3-aminobenzamide and related compounds. J. Exp. Bot. 1985, 36, 119-128. [CrossRef]

139. Schulz, P.; Jansseune, K.; Degenkolbe, T.; Méret, M.; Claeys, H.; Skirycz, A.; Teige, M.; Willmitzer, L.; Hannah, M.A. Poly(ADP-ribose)polymerase activity controls plant growth by promoting leaf cell number. PLoS ONE 2014, 9, e90322. [CrossRef]

140. Adams-Phillips, L.; Wan, J.; Tan, X.; Dunning, F.M.; Meyers, B.C.; Michelmore, R.W.; Bent, A.F. Discovery of ADP-ribosylation and other plant defense pathway elements through expression profiling of four different Arabidopsis-Pseudomonas R-avr interactions. Mol. Plant Micr. Interact. 2008, 21, 646-657. [CrossRef] [PubMed]

141. Kilian, J.; Whitehead, D.; Horak, J.; Wanke, D.; Weinl, S.; Batistic, O.; D'Angelo, C.; Bornberg-Bauer, E.; Kudla, J.; Harter, K. The AtGenExpress global stress expression data set: Protocols, evaluation and model data analysis of UV-B light, drought and cold stress responses. Plant J. 2007, 50, 347-363. [CrossRef]

142. Perera, I.Y.; Hung, C.-Y.; Moore, C.D.; Stevenson-Paulik, J.; Boss, W.F. Transgenic Arabidopsis plants expressing the type 1 inositol 5-phosphatase exhibit increased drought tolerance and altered abscisic acid signaling. Plant Cell 2008, 20, 2876-2893. [CrossRef] [PubMed]

143. Zhang, Y.; Xu, W.; Li, Z.; Deng, X.W.; Wu, W.; Xue, Y. F-Box protein DOR functions as a novel inhibitory factor for abscisic acid-induced stomatal closure under drought stress in Arabidopsis. Plant Physiol. 2008, 148, 2121-2133. [CrossRef]

144. Mizoguchi, M.; Umezawa, T.; Nakashima, K.; Kidokoro, S.; Takasaki, H.; Fujita, Y.; Yamaguchi-Shinozaki, K.; Shinozaki, K. Two closely related subclass II SnRK2 protein kinases cooperatively regulate drought-inducible gene expression. Plant Cell Physiol. 2010, 51, 842-847. [CrossRef]

145. Chan, Z.; Grumet, R.; Loescher, W. Global gene expression analysis of transgenic, mannitol-producing, and salt-tolerant Arabidopsis thaliana indicates widespread changes in abiotic and biotic stress-related genes. J. Exp. Bot. 2011, 62, 4787-4803. [CrossRef] [PubMed]

146. Bhaskara, G.B.; Nguyen, T.T.; Verslues, P.E. Unique drought resistance functions of the Highly ABA-Induced clade A protein phosphatase 2Cs. Plant Physiol. 2012, 160, 379-395. [CrossRef]

147. Kinoshita, N.; Wang, H.; Kasahara, H.; Liu, J.; MacPherson, C.; Machida, Y.; Kamiya, Y.; Hannah, M.A.; Chua, N.-H. IAA-Ala Resistant3, an evolutionarily conserved target of miR167, mediates Arabidopsis root architecture changes during high osmotic stress. Plant Cell 2012, 24, 3590-3602. [CrossRef] 
148. Berger, F.; Ramirez-Hernandez, M.H.; Ziegler, M. The new life of a centenarian: Signalling functions of NAD(P). Trends Biochem. Sci. 2004, 29, 111-118. [CrossRef] [PubMed]

149. Sánchez, J.-P.; Duque, P.; Chua, N.-H. ABA activates ADPR cyclase and cADPR induces a subset of ABA-responsive genes in Arabidopsis. Plant J. 2004, 38, 381-395. [CrossRef]

150. Dodd, A.N.; Gardner, M.J.; Hotta, C.T.; Hubbard, K.E.; Dalchau, N.; Love, J.; Assie, J.-M.; Robertson, F.C.; Jakobsen, M.K.; Goncalves, J.; et al. The Arabidopsis circadian clock incorporates a cADPR-based feedback loop. Science 2007, 318, 1789-1792. [CrossRef] [PubMed]

151. Allen, G.J.; Muir, S.R.; Sanders, D. Release of $\mathrm{Ca}^{2+}$ from individual plant vacuoles by both InsP3 and cyclic ADP-ribose. Science 1995, 268, 735-737. [CrossRef]

152. Wu, Y.; Kuzma, J.; Maréchal, E.; Graeff, R.; Lee, H.C.; Foster, R.; Chua, N.-H. Abscisic acid signaling through cyclic ADP-ribose in plants. Science 1997, 278, 2126-2130. [CrossRef]

153. Abdul-Awal, S.M.; Hotta, C.T.; Davey, M.P.; Dodd, A.N.; Smith, A.G.; Webb, A.A.R. NO-mediated $\left[\mathrm{Ca}^{2+}\right]_{\mathrm{cyt}}$ increases depend on ADP-ribosyl cyclase activity in Arabidopsis. Plant Physiol. 2016, 171, 623-631. [CrossRef] [PubMed]

154. Leckie, C.P.; McAinsh, M.R.; Allen, G.J.; Sanders, D.; Hetherington, A.M. Abscisic acid-induced stomatal closure mediated by cyclic ADP-ribose. Proc. Natl. Acad. Sci. USA 1998, 95, 15837-15842. [CrossRef] [PubMed]

155. Peiter, E. The plant vacuole: Emitter and receiver of calcium signals. Cell Calcium 2011, 50, 120-128. [CrossRef] [PubMed]

156. Bouche, N.; Bouchez, D. Arabidopsis gene knockout: Phenotypes wanted. Curr. Opin. Plant Biol. 2001, 4, 111-117. [CrossRef]

157. Lloyd, J.; Meinke, D. A comprehensive dataset of genes with a loss-of-function mutant phenotype in Arabidopsis. Plant Physiol. 2012, 158, 1115-1129. [CrossRef]

158. Hauser, M.T.; Morikami, A.; Benfey, P.N. Conditional root expansion mutants of Arabidopsis. Development 1995, 121, 1237-1252.

159. Kurata, T.; Yamamoto, K.T. petit1, a conditional growth mutant of Arabidopsis defective in sucrose-dependent elongation growth. Plant Physiol. 1998, 118, 793-801. [CrossRef]

160. Hicks, K.A.; Millar, A.J.; Carre, I.A.; Somers, D.E.; Straume, M.; MeeksWagner, D.R.; Kay, S.A. Conditional circadian dysfunction of the Arabidopsis early-flowering 3 mutant. Science 1996, 274, 790-792. [CrossRef] [PubMed]

161. Lorrain, S.; Lina, B.Q.; Auriac, M.C.; Kroj, T.; Saindrenan, P.; Nicole, M.; Balague, C.; Roby, D. Vascular associated death1, a novel gram domain-containing protein, is a regulator of cell death and defense responses in vascular tissues. Plant Cell 2004, 16, 2217-2232. [CrossRef]

162. Millar, A.A.; Gubler, F. The Arabidopsis GAMYB-like genes, MYB33 and MYB65, are MicroRNA-regulated genes that redundantly facilitate anther development. Plant Cell 2005, 17, 705-721. [CrossRef]

163. Geissler, T.; Wessjohann, L.A. A whole-plant microtiter plate assay for drought stress tolerance-inducing effects. J. Plant Growth Regul. 2011, 30, 504-511. [CrossRef]

164. Felix, G.; Duran, J.D.; Volko, S.; Boller, T. Plants have a sensitive perception system for the most conserved domain of bacterial flagellin. Plant J. 1999, 18, 265-276. [CrossRef] [PubMed]

165. Kunze, G.; Zipfel, C.; Robatzek, S.; Niehaus, K.; Boller, T.; Felix, G. The N terminus of bacterial elongation factor Tu elicits innate immunity in Arabidopsis plants. Plant Cell 2004, 16, 3496-3507. [CrossRef] [PubMed]

166. Thor, K.; Peiter, E. Cytosolic calcium signals elicited by the pathogen-associated molecular pattern flg22 in stomatal guard cells are of an oscillatory nature. New Phytol. 2014, 204, 873-881. [CrossRef] [PubMed]

167. Berglund, T.; Kalbin, G.; Strid, A.; Rydstrom, J.; Ohlsson, A.B. UV-B- and oxidative stress-induced increase in nicotinamide and trigonelline and inhibition of defensive metabolism induction by poly(ADP-ribose)polymerase inhibitor in plant tissue. FEBS Lett. 1996, 380, 188-193. [CrossRef]

168. Feng, B.M.; Ma, S.S.; Chen, S.X.; Zhu, N.; Zhang, S.X.; Yu, B.; Yu, Y.; Le, B.; Chen, X.M.; Dinesh-Kumar, S.P.; et al. PARylation of the forkhead-associated domain protein DAWDLE regulates plant immunity. EMBO Rep. 2016, 17, 1799-1813. [CrossRef] [PubMed]

169. Ahlfors, R.; Lang, S.; Overmyer, K.; Jaspers, P.; Brosché, M.; Taurianinen, A.; Kollist, H.; Tuominen, H.; Belles-Boix, E.; Piippo, M.; et al. Arabidopsis RADICAL-INDUCED CELL DEATH1 belongs to the WWE protein-protein interaction domain protein family and modulates abscisic acid, ethylene, and methyl jasmonate responses. Plant Cell 2004, 16, 1925-1937. [CrossRef] 
170. Jaspers, P.; Overmyer, K.; Wrzaczek, M.; Vainonen, J.P.; Blomster, T.; Salojärvi, J.; Reddy, R.A.; Kangasjärvi, J. The RST and PARP-like domain containing SRO protein family: Analysis of protein structure, function and conservation in land plants. BMC Genom. 2010, 11, 170. [CrossRef] [PubMed]

171. You, J.; Zong, W.; Du, H.; Hu, H.; Xiong, L. A special member of the rice SRO family, OsSRO1c, mediates responses to multiple abiotic stresses through interaction with various transcription factors. Plant Mol. Biol. 2014, 84, 693-705. [CrossRef]

172. Siddiqua, B.; Qamarunnisa, S.; Azhar, A. RCD1 homologues and their constituent WWE domain in plants: Analysis of conservation through phylogeny methods. Biologia 2016, 71, 642-650. [CrossRef]

173. Belles-Boix, E.; Babiychuk, E.; Van Montagu, M.; Inzé, D.; Kushnir, S. CEO1, a new protein from Arabidopsis thaliana, protects yeast against oxidative damage. FEBS Lett. 2000, 482, 19-24. [CrossRef]

174. Jaspers, P.; Blomster, T.; Brosché, M.; Salojärvi, J.; Ahlfors, R.; Vainonen, J.P.; Reddy, R.A.; Immink, R.; Angenent, G.; Turck, F.; et al. Unequally redundant RCD1 and SRO1 mediate stress and developmental responses and interact with transcription factors. Plant J. 2009, 60, 268-279. [CrossRef]

175. Liu, S.; Liu, S.; Wang, M.; Wei, T.; Meng, C.; Wang, M.; Xia, G. A wheat SIMILAR TO RCD-ONE gene enhances seedling growth and abiotic stress resistance by modulating redox homeostasis and maintaining genomic integrity. Plant Cell 2014, 26, 164-180. [CrossRef] [PubMed]

176. Overmyer, K.; Tuominen, H.; Kettunen, R.; Betz, C.; Langebartels, C.; Sandermann, H.; Kangasjärvi, J. Ozone-sensitive Arabidopsis $r c d 1$ mutant reveals opposite roles for ethylene and jasmonate signaling pathways in regulating superoxide-dependent cell death. Plant Cell 2000, 12, 1849-1862. [CrossRef]

177. Fujibe, T.; Saji, H.; Arakawa, K.; Yabe, N.; Takeuchi, Y.; Yamamoto, K.T. A methyl viologen-resistant mutant of Arabidopsis, which is allelic to ozone-sensitive $r c d 1$, is tolerant to supplemental ultraviolet-B irradiation. Plant Physiol. 2004, 134, 275-285. [CrossRef] [PubMed]

178. Teotia, S.; Lamb, R.S. The paralogous genes RADICAL-INDUCED CELL DEATH1 and SIMILAR TO RCD ONE1 have partially redundant functions during Arabidopsis development. Plant Physiol. 2009, 151, 180-198. [CrossRef]

179. Fujibe, T.; Saji, H.; Watahiki, M.K.; Yamamoto, K.T. Overexpression of the RADICAL-INDUCED CELL DEATH1 (RCD1) gene of Arabidopsis causes weak $r c d 1$ phenotype with compromised oxidative-stress responses. Biosci. Biotechnol. Biochem. 2006, 70, 1827-1831. [CrossRef]

180. Katiyar-Agarwal, S.; Zhu, J.; Kim, K.; Agarwal, M.; Fu, X.; Huang, A.; Zhu, J.-K. The plasma membrane $\mathrm{Na}^{+} / \mathrm{H}^{+}$antiporter SOS1 interacts with RCD1 and functions in oxidative stress tolerance in Arabidopsis. Proc. Natl. Acad. Sci. USA 2006, 103, 18816-18821. [CrossRef]

181. Overmyer, K.; Brosché, M.; Pellinen, R.; Kuittinen, T.; Tuominen, H.; Ahlfors, R.; Keinänen, M.; Saarma, M.; Scheel, D.; Kangasjärvi, J. Ozone-induced programmed cell death in the Arabidopsis radical-induced cell death1 mutant. Plant Physiol. 2005, 137, 1092-1104. [CrossRef] [PubMed]

182. Jiang, L.; Wang, Y.; Bjorn, L.O.; Li, S. Arabidopsis radical-induced cell death1 is involved in UV-B signaling. Photochem. Photobiol. Sci. 2009, 8, 838-846. [CrossRef] [PubMed]

183. Morales, L.O.; Brosche, M.; Vainonen, J.P.; Sipari, N.; Lindfors, A.V.; Strid, A.; Aphalo, P.J. Are solar UV-Band UV-A-dependent gene expression and metabolite accumulation in Arabidopsis mediated by the stress response regulator RADICAL-INDUCED CELL DEATH1? Plant Cell Environ. 2015, 38, 878-891. [CrossRef]

184. Wirthmueller, L.; Asai, S.; Rallapalli, G.; Sklenar, J.; Fabro, G.; Kim, D.S.; Lintermann, R.; Jaspers, P.; Wrzaczek, M.; Kangasjärvi, J.; et al. Arabidopsis downy mildew effector HaRxL106 suppresses plant immunity by binding to RADICAL-INDUCED CELL DEATH1. New Phytol. 2018, 220, 232-248. [CrossRef]

185. He, R.; Drury, G.E.; Rotari, V.I.; Gordon, A.; Willer, M.; Farzaneh, T.; Woltering, E.J.; Gallois, P. Metacaspase-8 modulates programmed cell death induced by ultraviolet light and $\mathrm{H}_{2} \mathrm{O}_{2}$ in Arabidopsis. J. Biol. Chem. 2008, 283, 774-783. [CrossRef]

186. Brosché, M.; Blomster, T.; Salojärvi, J.; Cui, F.; Sipari, N.; Leppälä, J.; Lamminmäki, A.; Tomai, G.; Narayanasamy, S.; Reddy, R.A.; et al. Transcriptomics and functional genomics of ROS-induced cell death regulation by RADICAL-INDUCED CELL DEATH1. PLoS Genet. 2014, 10, e1004112. [CrossRef] [PubMed]

187. Zhu, Y.; Du, B.; Qian, J.; Zou, B.; Hua, J. Disease resistance gene-induced growth inhibition is enhanced by $r c d 1$ independent of defense activation in Arabidopsis. Plant Physiol. 2013, 161, 2005-2013. [CrossRef] [PubMed] 
188. Pelagio-Flores, R.; Ruiz-Herrera, L.F.; López-Bucio, J. Serotonin modulates Arabidopsis root growth via changes in reactive oxygen species and jasmonic acid-ethylene signaling. Physiol. Plant 2016, 158, 92-105. [CrossRef]

189. Irani, S.; Todd, C.D. Exogenous allantoin increases Arabidopsis seedlings tolerance to $\mathrm{NaCl}$ stress and regulates expression of oxidative stress response genes. J. Plant Physiol. 2018, 221, 43-50. [CrossRef]

190. Hiltscher, H.; Rudnik, R.; Shaikhali, J.; Heiber, I.; Mellenthin, M.; Duarte, I.M.; Schuster, G.; Kahmann, U.; Baier, M. The radical induced cell death protein 1 (RCD1) supports transcriptional activation of genes for chloroplast antioxidant enzymes. Front. Plant Sci. 2014, 5, 475. [CrossRef] [PubMed]

191. Kjaersgaard, T.; Jensen, M.K.; Christiansen, M.W.; Gregersen, P.; Kragelund, B.B.; Skriver, K. Senescence-associated barley NAC (AM, $\underline{A} T A F 1,2, \underline{C U C)}$ transcription factor interacts with Radical-induced Cell Death 1 through a disordered regulatory domain. J. Biol. Chem. 2011, 286, 35418-35429. [CrossRef] [PubMed]

192. Vainonen, J.P.; Jaspers, P.; Wrzaczek, M.; Lamminmäki, A.; Reddy, R.A.; Vaahtera, L.; Brosche, M.; Kangasjärvi, J. RCD1-DREB2A interaction in leaf senescence and stress responses in Arabidopsis thaliana. Biochem. J. 2012, 442, 573-581. [CrossRef]

193. Sakuma, Y.; Maruyama, K.; Qin, F.; Osakabe, Y.; Shinozaki, K.; Yamaguchi-Shinozaki, K. Dual function of an Arabidopsis transcription factor DREB2A in water-stress-responsive and heat-stress-responsive gene expression. Proc. Natl. Acad. Sci. USA 2006, 103, 18822-18827. [CrossRef] [PubMed]

194. Jaspers, P.; Brosché, M.; Overmyer, K.; Kangasjärvi, J. The transcription factor interacting protein RCD1 contains a novel conserved domain. Plant Signal. Behav. 2010, 5, 78-80. [CrossRef]

195. Tossavainen, H.; Hellman, M.; Vainonen, J.P.; Kangasjärvi, J.; Permi, P. ${ }^{1} \mathrm{H},{ }^{13} \mathrm{C}$ and ${ }^{15} \mathrm{~N}$ NMR chemical shift assignments of $A$. thaliana RCD1 RST. Biomol. NMR Assign. 2017, 11, 207-210. [CrossRef]

196. O'Shea, C.; Staby, L.; Bendsen, S.K.; Tidemand, F.G.; Redsted, A.; Willemoes, M.; Kragelund, B.B.; Skriver, K. Structures and short linear motif of disordered transcription factor regions provide clues to the interactome of the cellular hub protein Radical-induced Cell Death1. J. Biol. Chem. 2017, 292, 512-527. [CrossRef] [PubMed]

197. Kragelund, B.B.; Jensen, M.K.; Skriver, K. Order by disorder in plant signaling. Trends Plant Sci. 2012, 17, 625-632. [CrossRef]

198. Teotia, S.; Lamb, R.S. RCD1 and SRO1 are necessary to maintain meristematic fate in Arabidopsis thaliana. J. Exp. Bot. 2011, 62, 1271-1284. [CrossRef]

199. Babajani, G.; Effendy, J.; Plant, A.L. Sl-SROl1 increases salt tolerance and is a member of the radical-induced cell death 1-similar to RCD1 gene family of tomato. Plant Sci. 2009, 176, 214-222. [CrossRef]

200. Borsani, O.; Zhu, J.; Verslues, P.E.; Sunkar, R.; Zhu, J.-K. Endogenous siRNAs derived from a pair of natural cis-antisense transcripts regulate salt tolerance in Arabidopsis. Cell 2005, 123, 1279-1291. [CrossRef]

201. You, J.; Zong, W.; Li, X.; Ning, J.; Hu, H.; Li, X.; Xiao, J.; Xiong, L. The SNAC1-targeted gene OsSRO1c modulates stomatal closure and oxidative stress tolerance by regulating hydrogen peroxide in rice. J. Exp. Bot. 2013, 64, 569-583. [CrossRef] [PubMed]

202. Sharma, S.; Kaur, C.; Singla-Pareek, S.L.; Sopory, S.K. OsSRO1a interacts with RNA binding domain-containing protein (OsRBD1) and functions in abiotic stress tolerance in yeast. Front. Plant Sci. 2016, 7, 62. [CrossRef]

203. Li, X.; Xu, Y.; Liu, F.; Zhao, M.; Sun, Y.; Ma, Q. Maize similar to RCD1 gene induced by salt enhances Arabidopsis thaliana abiotic stress resistance. Biochem. Biophys. Res. Commun. 2018, 503, 2625-2632. [CrossRef]

204. Jiang, H.; Xiao, Y.; Zhu, S. Genome-wide identification, systematic analysis and characterization of SRO family genes in maize (Zea mays L.). Acta Physiol. Plant 2018, 40, 176. [CrossRef]

205. Wu, Z.; Liang, J.; Zhang, S.; Zhang, B.; Zhao, Q.; Li, G.; Yang, X.; Wang, C.; He, J.; Yi, M. A canonical DREB2-type transcription factor in lily is post-translationally regulated and mediates heat stress response. Front. Plant Sci. 2018, 9, 243. [CrossRef]

206. Wahlberg, E.; Karlberg, T.; Kouznetsova, E.; Markova, N.; Macchiarulo, A.; Thorsell, A.-G.; Pol, E.; Frostell, A.; Ekblad, T.; Öncü, D.; et al. Family-wide chemical profiling and structural analysis of PARP and tankyrase inhibitors. Nat. Biotechnol. 2012, 30, 283-288. [CrossRef]

207. Ramegowda, V.; Senthil-Kumar, M. The interactive effects of simultaneous biotic and abiotic stresses on plants: Mechanistic understanding from drought and pathogen combination. J. Plant Physiol. 2015, 176, 47-54. [CrossRef] [PubMed] 
208. Pandey, P.; Irulappan, V.; Bagavathiannan, M.V.; Senthil-Kumar, M. Impact of Combined Abiotic and Biotic Stresses on Plant Growth and Avenues for Crop Improvement by Exploiting Physio-morphological Traits. Front. Plant Sci. 2017, 8. [CrossRef]

209. Zhang, H.N.; Sonnewald, U. Differences and commonalities of plant responses to single and combined stresses. Plant J. 2017, 90, 839-855. [CrossRef] [PubMed] 